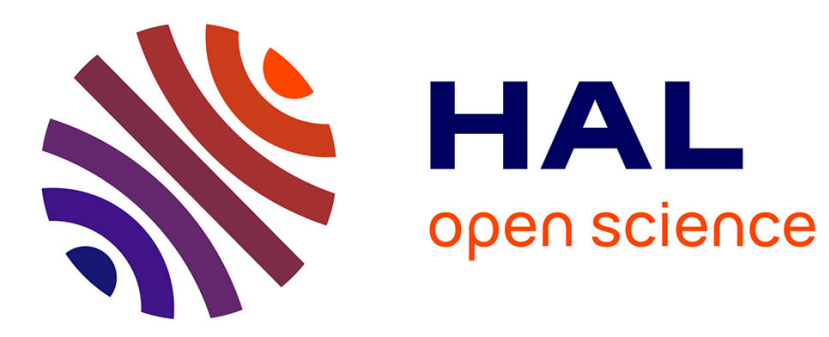

\title{
Gender Differences in Sorting
}

Luca Paolo Merlino, Dario Pozzoli, Pierpaolo Parrotta

\section{To cite this version:}

Luca Paolo Merlino, Dario Pozzoli, Pierpaolo Parrotta. Gender Differences in Sorting. Industrial Relations, 2018, 57 (4), pp.671-709. 10.1111/irel.12216 . hal-01687343

\section{HAL Id: hal-01687343 https://hal.science/hal-01687343}

Submitted on 18 Jan 2018

HAL is a multi-disciplinary open access archive for the deposit and dissemination of scientific research documents, whether they are published or not. The documents may come from teaching and research institutions in France or abroad, or from public or private research centers.
L'archive ouverte pluridisciplinaire HAL, est destinée au dépôt et à la diffusion de documents scientifiques de niveau recherche, publiés ou non, émanant des établissements d'enseignement et de recherche français ou étrangers, des laboratoires publics ou privés. 


\title{
Gender Differences in Sorting*
}

\author{
Luca Paolo Merlino $^{\perp} \quad$ Dario Pozzoli $\quad$ Pierpaolo Parrotta $\neg$
}

\begin{abstract}
In this paper, we investigate gender differences in workers' career development within and outside the firm to explain the existence of gender wage gaps. Using Danish employeremployee matched data, we find that good female workers are more likely to move to better firms than men but are less likely to be promoted. Furthermore, these differences in career advancement widen after the first child is born. Our findings suggest that career impediments in certain firms cause the most productive female workers to seek better jobs in firms where there is less gender bias.
\end{abstract}

JEL Classification: J16, J24, J62.

Keywords: Sorting, Assortative Matching, Gender Gap.

\footnotetext{
* We thank Estelle Cantillon, Francis Kramarz, Fane Groes, Rafael Lalive, Patrick Legros, Nina Smith and the participants of the COSME workshop (2013), the Search and Matching Conference (2014) and the workshop on Gender and Ethnic Differentials (2014) for their helpful comments and suggestions. We gratefully acknowledge funding from the Danish Council for Independent Research/Social Sciences, Grant no. x12-124857/FSE; LMDG, the Department of Economics and Business, Aarhus University; the ERC through grant 208535; the Wiener Wissenschafts-, Forschungs- und Technologiefonds (WWTF) under project fund MA 09-017; the Carlsberg Foundation; and the Swiss National Centre of Competence in Research LIVES and FNRS. The data used in this paper build on anonymized micro data sets owned by Statistics Denmark (SD). In the interest of scientific validation of analyses published using DS micro data, the Department of Economics and Business, Aarhus University, will assist researchers in obtaining access to the data set. The usual disclaimer applies.

${ }^{\perp}$ University of Antwerp and Université Paris 1- Panthéon Sorbonne. Email: LucaPaolo.Merlino@uantwerpen.be.

$\lceil$ Corresponding author. Copenhagen Business School, Department of Economics, Porcelaenshaven 16 A, DK2000 Frederiksberg. IZA, the Institute for the Study of Labor. Tuborg Research Centre for Globalisation and Firms, Aarhus University. InSTED, Department of Economics at University of Exeter Business School. Email: dp.eco@cbs.dk.
}

\footnotetext{
$\neg$ ICN Business School. IZA, the Institute for the Study of Labor. Tuborg Research Centre for Globalisation and Firms, Aarhus University. BETA, Bureau d'Économie Théorique et Appliquée. NoCeT, Norwegian Center for Taxation. ROA, Research Centre for Education and the Labour Market. E-mail: Pierpaolo.Parrotta@icn-groupe.fr.
} 


\section{Introduction}

Recent studies exploit the availability of matched employee-employer data to report that wage gaps between male and female workers arise as a result of segregation in lower-paying occupations, in less-productive establishments and in lower-paying occupations within establishments (Bayard, Hellerstein, Neumark, and Troske, 2003; Hellerstein and Neumark, 2008). Card, Cardoso, and Kline (2016) find that, while women negotiate lower wages than men with the same employer, they are also less likely to work in firms that pay higher premiums to either gender.

These studies show that wage gaps in the labor market are related to gender differences in the extent to which better workers are employed in better positions, i.e., in the degree of positive assortative matching (Becker, 1973).

Our paper differs from the existing literature because it explains the gender gap from a new perspective by examining workers' career development within and outside the firm.

When we examine gender differences in sorting in Denmark, surprising patterns emerge. Female workers of good types (proxied by the residual predicted from a Mincerian log-wage regression) are more likely to move to a better firm than similarly ranked male workers, conditional on workers changing employers. This is quite puzzling given the significant gender wage gap in Denmark (around 15 percent in the Danish private sector-see Gallen, 2015) and that the representation of women among legislators, senior officials and managers is relatively low.'

We then turn our attention to transitions within the firm to determine whether there are gender biases in promotions. There, a quite different pattern emerges: male workers of good types are more likely to be promoted than similarly ranked female workers conditional on workers not changing employers.

The objective of this paper is to explain this apparently conflicting evidence by accounting for the fact that workers move up the job ladder in two ways: either they are promoted by the current employer, or they find a better employer. Studying career development within and outside the firm as a unified sorting problem allows us to relate the patterns that we observe. Our findings suggest that career impediments in certain firms cause the most productive female workers to seek better jobs in firms with less gender bias. In our interpretation, segregation and gender gaps emerge because of the costs associated with changing employers combined with the career impediments that female workers face. As a result, consistent with the findings of Card, Cardoso, and Kline (2016), only the best female workers can pursue career advancement via job transitions, and they climb the occupational ladder more slowly than men.

To detect sorting patterns, we apply and extend the methodology proposed by Bartolucci and Devicienti (2013) to study both internal and external carreer advancements across genders. In particular, (i) we exploit within-firm variation in wages to rank workers within firms and conditional on observables. Intuitively, while a worker's type is not observable to the econometrician, it is observable to the firm, which then pays her/him accordingly. Furthermore, (ii) we use profits to rank firms, as maximizing profits is an objective for all firms. In a stylized

theoretical framework, we demonstrate that this estimation strategy allows us to analyze gender differences in sorting both within and across firms when workers care about wages. 
We then use these rankings to predict separately by gender (a) the probability that a worker moves to a better firm, i.e., a firm that makes higher profits, conditional on changing firms (being a mover), and (b) the probability of being promoted to a higher occupational level conditional on staying employed in a given firm (being a stayer). In our analysis, we use Danish employer-employee matched data for two important reasons. First, a representative and large sample of both workers and firms allows us to trace workers' career developments. Second, Denmark has a very flexible labor market, similar to that in the U.S. Hence, our analysis is relevant beyond the case of Denmark.

In line with the predictions of our theoretical framework, when we plot the probability of a job transition against a worker's type, we find a U-shaped relationship that is steeper for transitions to a better firm: while bad workers are likely to be replaced, the best workers are likely to move to better firms (Figure 1).

The findings depicted in Figures 2 and 3 that positive sorting is stronger in job transitions but weaker in promotions for female workers are confirmed by our regression models in which we add several controls. Specifically, a one-standard-deviation increase in the log of lagged wages increases the probability of moving to a better firm by 2 percent for female workers and by approximately half as much for male workers, while it increases the probability of promotion by 19 percent for female workers and by 31 percent for male workers. These gender differences are sizable, significant and stable, as they arise in a number of different specifications and tests. Most important, the same patterns emerge when we use other methods to rank workers and firms.

Note, however, that if all firms had the same attitude toward female workers, we would observe the same sorting patterns in transitions both within and across firms. Thus, our findings strongly indicate that female workers face more career impediments in certain firms and that they attempt to overcome these barriers by searching for better jobs in fairer companies. This interpretation is further corroborated by the fact that negligible gender differences arise when we examine promotions to higher occupational levels in the firms to which good female workers tend to move. Such firms are also highly profitable, which suggests that the best firms are those with non-discriminatory policies.i

The gender differences in sorting that we uncover for job transitions are possibly explained by female and male workers pursuing different routes to achieve career advancement due to career impediments in certain firms. This overall interpretation of our main findings is further supported by the fact that gender differences in job transitions disappear when transitions are not voluntary (e.g., when they are driven by a firm's closure).

Another interesting result is that gender differences in promotions appear to emerge especially after workers become parents, a fact that is not related to firms' observable characteristics such as sector or size.

Our analysis is related to Card, Cardoso, and Kline (2016). Using Portuguese matched worker-firm data, the authors decompose firm-specific pay differentials into a combination of sorting and bargaining effects by implementing the methodology proposed by Abowd, Kramarz, and Margolis (1999), which we discuss further in Section 2. Specifically, Card et al. (2016) find that, compared to men, women are less likely to be employed at higher-wage firms and to gain a significant share of the surplus associated with their jobs. Although our study focuses on the Danish labor market, which differs from the Portuguese one along several dimensions, we 
interpret the interplay of career paths within and outside firms in our analysis as corroborative evidence in favor of the gender differences in bargaining power documented by Card et al. (2016).

Groes, Kircher, and Manovskii (2015) show that both low and high wage earners within an occupation are more likely to leave their occupation and that the high earners tend to move to new occupations with higher average wages. Interestingly, we find similar patterns when we examine workers changing firms. In addition, we focus on how the strength of this phenomenon differs across genders.

Our insights on promotions are also consistent with Booth, Francesconi, and Frank (2003). They find that men and women are equally likely to be promoted but women receive lower wage increases. This is the sticky floor phenomenon. Yet, Booth et al. (2003) do not look at transitions across employers. Hence, our study represents a significant advancement with respect to theirs.

Our finding that career impediments for women emerge after motherhood is in line with the evidence presented by Smith, Smith, and Verner (2013) for CEOs and with that of Kleven, Landais, and Søgaard (2015), who show that motherhood is a career impediment in certain firms but not in others. In particular, Kleven et al. (2015) find that most of the gender wage gap can be explained by a parenthood penalty that affects women but not men. In our study, we focus on the link between gender biases in promotions in certain firms and job transitions. Hence, we restrict our attention to sorting patterns of full-time workers, and we therefore model only one of the dynamic effects of having children on career developments.

Several authors find that women have a less elastic across-firms labor supply than men (Webber, 2016; Hirsch, 2016). This can result in wage gaps when firms set wages monopsonistically (Manning, 2003). Differently from those studies, we exploit within-firm variation to identify gender differences among (i) separated workers (movers) who move to better firms and (ii) non-separated workers (stayers) who are promoted to a better occupation. Thus, we are able to relate gender biases in promotions to the allocation of workers to firms.

The structure of the article is as follows. Section 2 describes our estimation strategy, the data and the institutional background. Section 3 includes the main results. Section 4 reports robustness checks and additional results. Section 5 offers concluding remarks.

\section{The Estimation Strategy}

The model of Merlino (2012) shows that negative biases against certain group of workers translates into differences in sorting that generates unemployment and wage gaps.

Detecting sorting patterns is however not a straightforward task, especially when agents' types are not observable (Filippin and Ours, 2015). Different approaches have been proposed to overcome this problem. Abowd, Kramarz, and Margolis (1999), henceforth AKM, use the correlation between workers' and firms' fixed effects derived from wage equations. Identification of the individual fixed effects relies upon the assumption that workers' movements between firms are conditionally random. In other words, after conditioning on the observable worker and firm effects, when a worker moves to a new firm, she draws at random from the existing firms in the economy. This assumption is challenged theoretically by 
on-the-job search (Eeckhout and Kircher, 2011). Intuitively, when workers voluntarily move to another firm, their compensation should improve.

Bartolucci and Devicienti (2013) address this issue by exploiting within-firm variation in wages to rank worker types (within firms) and profits to rank firms. All firms seek to maximize profits, and thus, it is natural to consider profits as a measure of firm "quality". Workers instead might care about many job characteristics beyond wages. Hence, wages might be a noisy measure of workers' quality.

While Card, Heining, and Kline (2013) propose tests to check the conditional exogenous mobility assumption of the original AKM method, Bartolucci, Devicienti, and Monzón (2015) design a method that does not rely on wages: they measure the variance of firm ranking (proxied by the arrival firm's profits per worker) that can be explained by the movers' types (proxied by the sending firm's profits per worker). The smaller the variance of firm types for a given worker type is relative to the unconditional variance of firm types, the more intensively workers sort into firms. Yet, this method cannot be used to assess sorting in promotions.

In this paper, we then use the methodology of Bartolucci and Devicienti (2013) to rank workers and firms because it allows us to analyze gender differences in sorting both within and across firms under the assumption that workers care mostly about wages. In Section 4, we show that our main results do not depend on this assumption, as implementing several other approaches to measure workers' ranks provides similar findings.

Our baseline empirical strategy is rooted in a simple theoretical framework with learning, job search and a production technology in which skills and capital are complements, i.e., that induces positive assortative matching. While the model is formally presented in the Appendix, we now present the main mechanisms it embeds.

In the model, there is a unit mass of workers and firms, with type indexed by $e$ and $f$, respectively. The productivity of the match is increasing in both the type of the worker and of the firm, and we consider a super-modular production function that induces positive assortative matching (Becker, 1973).

First, workers are randomly matched to firms. This assumption captures the idea that workers have little information regarding employer types at the beginning of their careers. As they acquire experience, workers might learn the characteristics of all firms in the market, and they also might become more productive.

We introduce learning by doing in the following way: during period 0 , workers acquire relevant experience that improves their skills as long as $e \geq f$. In other words, there are skill requirements: only agents that are sufficiently qualified understand the technology enough to improve their productivity. As a result, in the second period, some workers are more productive, i.e., they increase their type. Hence, a worker $e$ in a match in period 0 with a firm $f$ such that $e \geq f$ becomes of type $\tau e$ in period 1 .

However, some firms do not allow female workers who learned to express their acquired potential: for example, the suggestions they make to improve the productivity of the current match are not implemented, or they are not assigned to better tasks. Hence, good male workers are more likely to be promoted in the firm where they are currently employed than are female workers of similar type.

Subsequently, each pair can decide whether to stay together or to search for a better 
partner. Search is costly, but it allows that workers are matched to their best partner available. Hence, only agents that are sufficiently mismatched will change employers.

In equilibrium, female workers who (a) improve their type through learning but (b) are not promoted by the current employer are more likely to move to better firms with fairer promotion policies. More formally, we have the following:

Empirical Predictions. Consider $e_{m}$ and $e_{f}$ such that $e_{m}$ is male, $e_{f}$ is female and $e_{m}=e_{f}=e$. Then,

(i) the higher the type of a worker is, the higher the probability of moving to a better firm;

(ii) the probability of moving to a better firm from a given firm for $e_{f}$ with respect to $e_{f}-\Delta$ is higher than for $e_{m}$ with respect to $e_{m}-\Delta$, for $\Delta>0$; and

(iii) the probability of being promoted in a given firm for $e_{m}$ with respect to $e_{m}-\Delta$ is higher than for $e_{f}$ with respect to $e_{f}-\Delta$, for $\Delta>0$.

While wages are non-monotonic in firm type, in this model, wages and (both total and average) profits are increasing in own type. Hence, we can use within-firm variations in wages to rank workers and profits to rank firms. In our analysis, we therefore use these rankings to test the empirical predictions made above.

The theoretical framework explicitly shows that if female workers were to have the same career prospects in all firms, it would not be necessary to separately study gender differences in sorting within and across firms, as these should be comparable. This is true even if female workers' types are drawn from a worse distribution, as in that case the outside option is relatively more attractive for them than for men.

If instead firms are heterogeneous in their gender bias in promotions, female workers who learn but are not promoted in non-female-friendly firms are more likely to move to better firms that are female friendly. Conversely, good male workers are more likely to be promoted in the firm where they are currently employed. Hence, the association between the probability of moving to a better firm and wages should be higher for female workers, while the association between the probability of being promoted and wages should be stronger for male workers.

Let us stress that our estimation strategy is premised on the presence of mismatches between workers and firms as with perfect sorting no transitions would occurr. Yet, even in a flexible labor market, such as the Danish one, mismatches and frictions are likely to arise for a variety of reasons, such as commuting distances or non-monetary factors (Manning, 2003).

\subsection{Empirical Approach}

Based on this theoretical framework, we estimate the following linear probability model, which is conditional on workers' movements (i.e., for the sample of movers), separately for each gender:

$$
\text { move_up }{ }_{e t}\left(f, f^{\prime}\right)=\alpha_{0}+\alpha_{1} \text { wage }_{e t-1}(f)+x_{e t-1}{ }^{\prime} \beta+z_{f t-1}{ }^{\prime} \gamma_{1}+z_{f^{\prime} t}^{\prime} \gamma_{2}+z_{t}+u_{f}+\varepsilon_{e t}
$$

where move_up $\left(f, f^{\prime}\right)$ is a dummy variable that is equal to 1 if an employee of type $e$, who 
has worked in a sending firm of type $f$, moves to a "better" receiving firm of type $f^{\prime}>f$ at

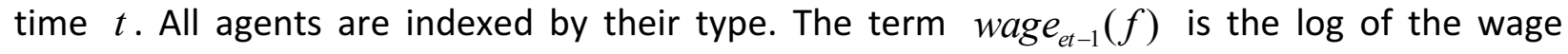
earned in sending firm $f$ by employee $e$. As there are many worker characteristics that may influence wages and mobility, such as demographic characteristics, and it is unclear to what extent the monotonicity assumption on payoffs is fulfilled when comparing coworkers in different occupations, we augment equation (1) with the vector $x_{e}$. The latter consists of relevant worker characteristics, such as age, tenure, work experience, iii ethnicity, marital status, parental status, education, occupation and a family network dummy (i.e., a dummy that records whether a worker has had at least one parent employed as a manager). The vectors $z_{f}$ and $z_{f^{\prime}}^{\prime}$ include the share of white-collar women and the size of the sending and receiving firm, ${ }^{\text {iv }}$ respectively, while the vector $z_{t}$ represents time fixed effects. Finally, $u_{f}$ captures the fixed effects of firm $f$, and $\varepsilon_{e t}$ is a mean-zero error term. ${ }^{v}$

The extent and sign of sorting in job transitions are tested by investigating whether the coefficient $\alpha_{1}$ is different from zero. Specifically, if $\alpha_{1}>0$, better workers (i.e., those workers who receive higher wages in a given firm after controlling for observables) are more likely to move to firms that earn higher profits, i.e., there is positive sorting. Furthermore, a more positive coefficient indicates a relatively stronger tendency toward positive assortative matching.

The focus of this paper is to test whether the degree and sign of sorting in job transitions vary according to gender by estimating equation (1) separately by gender and testing whether $\alpha_{1}$ significantly varies across the female and male sub-samples. We test for sorting differences between men and women by comparing estimations from each sub-sample since within-firm rankings are highly gender-specific.

With regard to the sample of stayers and their probability of being promoted, a similar model is implemented separately by gender:

$$
\operatorname{prom}_{e t}(f)=\alpha_{0}+\alpha_{1} \text { wage }_{e t-1}(f)+x_{e t-1}^{\prime} \beta+z_{f t}^{\prime} \gamma+z_{t}+u_{f}+v_{e t}
$$

where $\operatorname{prom}_{e t}(f)$ is a dummy variable that is equal to 1 if employee $e$, who has worked in a specific occupation in firm $f$, is promoted to a higher occupational level. Because of data constraints, we consider three main occupational groups: managers, middle managers and other white collar positions, and blue-collar workers. The term $u_{f}$ captures within-firm fixed effects. As in the previous model, the vectors $x_{e t-1}$ and $z_{f t}$ include worker and firm characteristics while the vectors $z_{t}$ are time dummies and $v_{e t}$ is an error term. ${ }^{\mathrm{vi}}$

\subsection{Data}

The data set, provided by Statistics Denmark, is a merged employer-employee panel sample of Danish firms observed over the 1996-2005 period.

The firm-level data include information on sales, employment, value added, materials, profits, fixed assets and a two-digit NACE identifier (further details are provided in section A-1 
of the Online Appendix). We consider firms in the private sector that have more than 20 employees. ${ }^{\text {vii }}$ All firms with imputed accounting variables are omitted from the analysis.

The individual-level data cover the working-age population from 1980 onward. These data include information on the wage, age, gender, marital status, number of children, experience, tenure, highest completed education, occupation and family background characteristics. Apart from deaths and permanent migration, there is no attrition in the data set. The labor market status of each person as of the last week in November is recorded as the relevant datum for each person for that year. Therefore, if a worker changes his or her main job, then we observe only the year in which this change occurred. However, we observe whether a worker experiences unemployment and its duration (in weeks) in a given calendar year. For individuals with multiple jobs, only the main occupation is considered.

In the analysis that follows, we include only individuals with a positive annual salary viii and individuals younger than 60. Furthermore, apprentices and part-time employees are excluded from the main analyses.

The empirical estimations are based on two samples. The first sample considers only "movers", i.e., those workers who, within the 1996-2005 period, changed at least once from one firm (the sending firm, according to our terminology) to another firm (the current or receiving firm) in the data set within the 1996-2005 period. ${ }^{\text {ix }}$ An important challenge regarding this data set is that, because of changes in firms' ownership, there appear to be some "false" transitions in the data. To minimize miscoded movers, transitions involving more than 50 percent of the size of the same sending firm are excluded from the final sample. Furthermore, we exclude from the sample of movers those workers who changed jobs after a firm closure. In total, our sample includes 479,161 yearly observations of 357,487 job movers (i.e., approximately 15 percent of the entire population of job movers) and approximately 17,000 firms. ${ }^{x}$ The second sample excludes the movers and consists of 4,658,374 observations, 617,513 "stayers" (i.e., approximately 25 percent of the entire population of stayers) and nearly 18,000 firms. The sample of movers is a lower share of the underlying population compared to the sample of stayers because of the removal of "false" and involuntary transitions as described above. As we discuss later in the results section, we also estimate all of our models on more general samples obtained by relaxing all of our sample selection criteria.

\subsection{Descriptive Analysis}

Table 1 separately lists the descriptive statistics for the two samples according to gender, measured at both the worker and firm level.

The average male job mover is 39 years of age and has 16 years of experience, whereas the average female job mover is 38 years of age and has 14 years of experience. The average tenure for both women and men is approximately three years. The majority of workers have secondary or post-secondary diplomas, and 6 percent of male job changers have at least a university degree, whereas 30 percent have completed only primary education. In addition, 7 percent of female job changers have at least a university degree, and 37 percent have a primary education. Most men and women are classified as blue-collar workers ( 72 percent), followed by middle managers (24-26 percent). Significantly more male movers have managerial jobs compared with their female counterparts ( 4 percent versus 2 percent, respectively). For both 
genders, approximately 5 percent are foreigners, nearly 15 percent have at least one child of 0-3 years of age, and around 4-5 percent have at least one parent working as a manager at the time of the job transition or before, i.e., a "family network". In comparison, the average stayer is approximately two years older and has two more years of tenure, with a slightly lower educational level. The average stayer is also more likely to be married and less likely to have a child between 0 and 3 years of age, regardless of the gender of the individual. The percentage of foreigners is reasonably comparable across the two samples. During the period covered by our sample, the wage of an average male and female job mover was approximately 250 and 200 thousand Danish krones, respectively, or approximately 40 and 30 thousand USD per annum, respectively. The salary of an average stayer was approximately 10 percent above that figure. Turning to the firm-level characteristics, we find that the average firm size is fairly similar across the two samples, although the share of white-collar women and profits per worker are higher in the sample of movers, regardless of the gender of the employee.

The bottom part of Table 1 includes the mean of the main outcome-dependent variables used in our empirical analysis. For the sample of job movers, we calculate an indicator function that takes value one (zero) if a worker moves to a receiving firm that is of higher (lower) quality than the sending firm. Firm type is defined in terms of profits. Given that the measure of profits is firm specific and might be affected by measurement error, we calculate a set of indicator variables that are based on alternative improvements in profits (i.e., the profit differential between sending and receiving firms is at least either 5 or 10 percent). The means of these outcome variables, also reported in Table 1, allow us to conclude that women have higher probabilities of moving to a receiving firm of higher quality, regardless of the definition of firm quality that we use. In addition, for the sample of stayers, we also examine the probability of promotion to a higher occupational level and to a managerial position. We find that women are generally less likely to be promoted than men.

As we report in Figures A1-A3 of the Online Appendix, whereas a somewhat decreasing gender wage gap characterizes workers who changed employers, stayers present a stable wage differential between men and women over time. More important, the wage developments have almost identical slopes across genders, suggesting that the career profiles of men and women are very likely to feature very similar initial conditions and match quality. Women earn substantially less than their male peers, but the differences are particularly marked for the sample of stayers. This descriptive evidence seems to suggest that more productive women are very likely to change workplaces to achieve higher wages and promotion rates. This evidence is not driven by educational and occupational levels or by the gender composition of the workforce.

\subsection{Institutional Background}

As institutional constraints may hamper the degree of assortativeness in the labor market, we outline the main features of the Danish labor market, which are represented by the combination of high flexibility and social security ("flexicurity"), the role of family-friendly policies and decentralized wage setting.

The cornerstones of the Danish model are a high level of labor mobility and generous social security schemes. The absence of severance pay reduces hiring and firing costs and labor 
market frictions and facilitates firms' efforts to adjust the quality and size of their workforce. Moreover, although workers are not protected by stringent employment rules, they bear relatively low costs of changing employers and have easy access to unemployment or social assistance benefits. In fact, Danish replacement ratios are among the most generous in the world. Therefore, a notable part of the observed labor mobility is also associated with wage mobility (Eriksson and Westergaard-Nielsen, 2009).

A further key feature of the Danish labor market is the wide coverage of publicly provided childcare. Combined with the length and flexibility of parental leave schemes, this has favored female labor market participation and full-time employment without dramatic consequences for the fertility rate (OECD, 2005). While many of the jobs held by women were initially part-time occupations in the public sector, at present, a notable proportion of women is employed in the private sector and works full-time. Nonetheless, the descriptive statistics show that women in the private sector earn a 5-percent higher wage and are slightly more educated compared to their counterparts in the public sector. These statistics may suggest that the sample used in this study is relatively selected, consisting of slightly more motivated and career-oriented women. Yet, we will see that even this sample of female workers encounters significant career impediments in some firms.

For the purposes of our analysis, a brief description of wage bargaining in the Danish private sector is also important. Denmark experienced a shift in wage bargaining from a highly centralized system to a substantially decentralized system. Since the early 1980s, an increasing share of wage bargaining has been devolved to the firm (individual employee) level. Currently, the within-firm wage variability in Denmark represents more than 80 percent of the total variability observed among all workers (Shaw and Lazear, 2008).

Given the key characteristics of the Danish labor market, the evidence of gender gaps arising from our empirical analysis may be generalized to other labor markets with similar degrees of flexibility.

\section{Results}

Given the large volume of results, we discuss them in two separate sub-sections. The first sub-section describes the main results of sorting in job transitions and promotions, while the second sub-section discusses some additional analysis and alternative specifications.

\subsection{Main Results}

We first analyze the main patterns present in the data using some intuitive figures that concisely describe the sorting patterns of workers of different types.

According to our theoretical framework, conditional on observables, the probability of leaving the current firm should be high for workers with low and high wages, while it should be lower for workers who are ranked neither too high nor too low in the wage distribution of the firm. Furthermore, this probability should be higher for women, for whom outside options are more attractive.

In Figure 1, we plot the probability of leaving the current firm for men and women as a 
function of their type, proxied by the residual predicted from a Mincerian log-wage regression in which we control for both observable individual characteristics and firm fixed effects. We find that high wages increase the probability of leaving the firm to a greater extent than do low wages, and this is particularly true for female workers.

To further understand these mobility patterns, we now investigate which workers are more likely to move to a better firm conditional on leaving a firm and which workers are more likely to be promoted conditional on not leaving, again depending on the residuals of a Mincerian log-wage equation.

Figure 2 shows that workers who change firms are more likely to move to a better firm the higher their rank in the sending firm is. Furthermore, good female workers are generally more likely to leave the current firm, expect possibly for very high types. Similar results are obtained for promotions (Figure 3), although in this case, male workers of good types are more likely to be promoted than similarly ranked female workers.

This suggests that women change firms because they are less likely to pursue career advancement in the current firm. To better understand these patterns, we now present the results of the estimation of a linear probability model (1). This approach has the advantage of allowing for an analysis of the different factors driving gender differences in sorting and how they change for different sub-samples of the population.

The main results pertaining to transitions to better firms are reported in the first two columns of Table 2 . For both men and women, there is a significantly positive elasticity of the probability of moving to a better firm with respect to the logarithm of the wage earned in the previous firm. These results are consistent with those of Bagger, Sørensen, and Vejlin (2013), who document strong positive sorting in Denmark. This evidence justifies the assumption of a production function that induces positive assortative matching.

Female workers display a substantially stronger tendency toward positive sorting in job transitions compared to men. Specifically, a one-standard-deviation increase in the log of lagged wages raises female workers' probability of moving to a better firm by 2 percent. The same increase has half as much of an effect on the male workers' probability of moving.

Hypothesis testing, reported at the bottom of Table 2, confirms that the coefficient estimated on women's lagged wages is statistically higher than that associated with men's wages. These empirical associations suggest that among movers better-ranked women are more likely to move to companies with higher profits compared to men. ${ }^{\mathrm{xi}}$

Interestingly, a rise in the share of white-collar women in the sending firms has opposite effects on sorting in the two sub-samples: it decreases the probability of moving for female workers, whereas it increases the corresponding probability for men.

This analysis of job transitions gives little support for the classical version of the glass ceiling hypothesis, which would imply that sorting is weaker for women than for men.

Let us now turn our attention to promotions, which are a proxy for career advancement within firms (columns 3-4 of Table 2). We find a general positive relationship between the lagged wage and the probability of being promoted for both genders. ${ }^{\text {ii }}$ However, this association is stronger for men, as confirmed by the hypothesis tests reported at the bottom of Table 2. A one-standard-deviation increase in the log of lagged wages raises female workers' promotion probability by 19 percent. The same increase triggers a rise in male workers' promotion probability of 31 percent. A greater share of white-collar women is associated with 
a higher conditional probability for both women and men. Thus the within firm increase in the share of female workers per se is not an indication of unbiased promotion policies. Gender differences in favor of men persist when we focus on substantial career advances, i.e., promotions to positions at the managerial level (see the last two columns of Table 2). ${ }^{\text {xii }}$

These results pertaining to promotions might qualify the findings indicating that a rise in the share of white-collar women in sending firms has a negative correlation with women's probability of moving to a better firm. As women are more likely to be promoted in female-friendly firms, i.e., firms with many white-collar female workers, they are less likely to seek a job elsewhere if the sending firm is female friendly. Furthermore, men have fewer incentives to seek a job outside of their current firm, especially in non-female-friendly firms, which implies stronger positive sorting for women in job transitions.

This explanation presumes the existence of firms that have no, or less, gender bias in promotions. We will now investigate whether such firms exist. To do so, we define female-friendly firms as companies characterized by a share of women in white-collar positions higher than the industrial median. Furthermore, we define "female-sought" firms as the female-friendly firms that are destinations in the job transition of at least one female worker coming from a worse firm.

The first panel of Table 3 shows that the sorting parameter in job transitions to female-friendly firms is larger. There are instead smaller and less significant gender differences for transitions to firms that are not female friendly. Hence, transitions to female-friendly firms drive the stronger positive sorting for female workers in job transitions.

Positive sorting in promotions is stronger for women when we examine promotions in female-friendly and female-sought firms (second panel of Table 3). However, the difference is consistent with the baseline results, but stronger, in firms that are not sought after by females. Hence, these findings strongly indicate that good female workers seek career advancement in female-friendly firms because promotion opportunities in these firms do not depend on gender.

Nonetheless, gender differences in favor of men for promotions to managerial positions seems to emerge in all firms (third panel of Table 3). Hence, only few female workers reach managerial positions. These results nicely complement those of Gayle, Golan, and Miller (2012), who find that female CEOs are more likely to exit their occupations but are also more likely to become CEOs when they have not exited.

According to our empirical strategy, female-friendly and female-sought firms perform, by construction, better than sending firms. In Table A4 of the Online Appendix, we explicitly assess the correlation between firm performance and female friendliness by estimating a set of firm performance equations with several control variables and an indicator variable for female friendliness, which is alternatively measured with either a "female-friendly firm" or "female-sought firm" dummy. We find a positive and significant correlation between being either a "female-friendly firm" or a "female-sought firm" and firms' profits per employee, sales per employee and value-added per employee.

Overall, the empirical results presented thus far are not consistent with the view that women have better non-market opportunities (Lazear and Rosen, 1990). In that case, women would be less likely to be promoted than men in all firms but more likely to receive higher wages if promoted and more likely to quit to pursue non-market opportunities. Instead, female 
workers are less likely to be promoted and are more likely to move to a better firm when career advancement is not too difficult to achieve. In fact, the evidence of gender differences in promotion strongly suggests that women who cannot climb the occupational ladder within a firm because of discriminatory promotion policies attempt to overcome these gender barriers by searching for better jobs offered by fairer firms. However, great career advancement tends to be easier to achieve for men than for women in all firms.

\section{Robustness and Additional Results}

In this section, we provide further evidence of the robustness of gender differences in sorting and of the mechanisms generating them.

\subsection{Definitions of Workers' Types}

With renegotiation and endogenous search intensity, wages provide a noisy ranking of workers (Bagger and Lentz, 2014). To evaluate whether this issue affects our analysis, we rank workers using employee fixed effects, which are estimated from a gender-specific wage equation. Specifically, the individual fixed effects are obtained by estimating the following wage regression:

$$
\ln w_{e f t}=\alpha_{e}+\psi_{f(e, t)}+\beta_{1} X_{e t}+\beta_{2} Z_{f t},+\varepsilon_{e f t}
$$

where $w_{e f t}$ is the gross annual wage earned by individual $e$ in firm $f$ in year $t . X_{e t}$ is a vector of individual-specific controls that change over time. Following Card et al. (2013), we include in $X_{e t}$ a set of interactions between year dummies and educational attainment and interaction terms between quadratic and cubic terms in age and educational attainment. In addition, we also control for other factors that might affect wages such as experience and tenure. The vector $Z_{f t}$ contains firm-specific controls, such as value added and capital per employee. The parameters $\alpha_{e}$ and $\psi_{f(e, t)}$ are the individual- and firm-specific fixed effects, respectively. We estimate this additive "two-way" worker-firm effects model using the methodology developed in AKM. ${ }^{\text {xiv }}$ The findings reported in Table 4 confirm the results of our main analysis.

We then measure the strength of sorting in job transitions using the method proposed by Bartolucci et al. (2015). While this approach cannot be used to evaluate sorting in promotions, it does not rely on wages. It measures the variance of firm rankings (proxied by the arrival or current firm's profits per worker) that can be explained by the movers' types (proxied by the sending firm's profits per worker). The smaller the variance of (firm) partner types for a given worker type relative to the unconditional variance of firm types, the more intensively workers sort into firms. Specifically, the strength of sorting is defined by the correlation ratio $\eta=\sqrt{\operatorname{var}[E[f \mid e]] / \sigma_{f}^{2}}$, where $\operatorname{var}[E[f \mid e]]$ represents the partners' variance for a given

worker of type $e$, whereas $\sigma_{f}^{2}$ is the variance of firm types $f$. We then estimate the correlation ratio $\eta$ as the mean of the correlation between the type of the sending firm $f$ 
and the arrival firm $f$ for all worker types $e$ (represented by the firm's profit per worker), defined as $\rho\left(f, f^{\prime} \mid e\right)=\operatorname{cov}\left(f, f^{\prime} \mid e\right) / \operatorname{var}(f)$. As in Bartolucci et al. (2015), we estimate $\rho$ using only transitions mediated by an interim unemployment spell to make $(f, e)$ and $\left(f^{\prime}, e\right)$ independent conditional on worker type $e$. The strength of sorting $\eta$ provides a measure of the association between firm type $f$ and worker type $e$. Finally, Bartolucci et al. (2015) estimate the sign of sorting by considering the empirical association between the sending firm's ranking and the mover's wage earned in current employment or, alternatively, between the receiving firm's ranking and the mover's wage earned in the previous employment.

When we implement these methodologies on job transitions, we find that the results are consistent with our main findings, as the estimated parameter $\eta$ is larger for women than for men and the sign of sorting is positive for both genders (Table 5). ${ }^{\mathrm{xv}}$

\subsection{Definitions of Firms' Types}

Profits are the objective of all firms. Furthermore, a precise estimate of mean profits for each firm can be recovered as long as there are a large number of workers per firm. However, our results for job transitions could be sensitive to the particular definition of firm quality we use (i.e., a firm is better than another when it has at least 5 percent higher profits). It is important to consider other ranking measures for firm types than profits also because these may be also determined by monopoly power or taxation.

We address this issue in different ways. First, we strengthen the conditions on profits by defining a transition to a better firm as a transition to a firm with profits that are at least 10 percent higher than those of the sending firm. This stronger requirement mitigates eventual measurement errors and corroborates the findings of the main specification (first two columns of the upper panel of Table 6).

Second, we estimate equation (1) using alternative methods to rank firms. As reported in Table A5 of the Online Appendix, we obtain qualitatively similar results using average profits over the sample period; past profits that were made before the job transition occurred; profits per worker; value added and total factor productivity (TFP) estimated separately by industry as in Parrotta and Pozzoli (2012).

\subsection{Definitions of Job Transitions}

Jobs differ in many dimensions beyond the type of the firm that offers them, and workers may take into consideration these other characteristics when deciding whether to change jobs. To control for this, we restrict the definition of job transitions to a better firm. Specifically, we impose the condition that movers earn higher wages or are employed at a higher occupational level after a transition to a better firm. Using these restrictive definitions of career improvements in job transitions, we find strong gender differences in sorting, in line with the baseline results (the first two columns of the bottom panel of Table 6). This corroborates the appropriateness of our theoretical framework.

As we mentioned in Section 2.2, because of changes in firms' ownership, there may be some "false" transitions in the data. We now assess the robustness of our main results by 
setting alternative criteria in order to minimize miscoded movers. First we exclude from the sample transitions involving more than either 20 or 10 percent of the size of the same sending firm. The first panel of Table A14 of the Online Appendix shows that the coefficients estimated on the worker's type hardly changes across the two sub-samples of movers and are very similar to the ones reported in Table 2. Second, given that when two or more firms are merged there can be a change of the firm identifier but not of the establishment's number, we identify job transitions by requiring a change of both the firm and of the establishment identifiers. In an additional robustness check we further narrow the definition of job transition by adding as a requirement a change of the workers' municipality of residence. We report the results from these restricted samples of movers in the second panel of Table A14 of the Online Appendix. Despite the coefficients are slightly different compared to those reported in the main analysis, gender differences in favor of women persist and confirm the main findings.

\subsection{Firm Exit}

Our results could arise because women are more skilled at finding a job outside the current firm. This could be because of a lower search cost or because of a higher investment in general versus specific human capital with respect to men.

We test these hypotheses by focusing solely on transitions from a firm's closure (last two columns of the bottom panel of Table 6) since these mobility patterns do not stem from the voluntary choices and career concerns of employees. Indeed, in such situations, all workers, including men, are forced to seek jobs outside of their current firms.

Interestingly, we find gender differences in sorting in favor of men in these job transitions (albeit not always significant differences). These results lend additional support to the fact that positive sorting in job transitions is stronger for women because of voluntary transitions triggered by gender biases in promotions in the sending firm.

\subsection{Results by Cohort}

The sorting patterns that we document could be due to a worse initial allocation of women to firms with respect to men. This would imply that positive sorting in job transitions should be stronger for women and especially so for younger female workers. Furthermore, wage increases should be steeper for women. Alternatively, there could be intrinsic biological differences (Ichino and Moretti, 2009): since women's rate of absenteeism is generally higher than that of men, the former are less productive (or their productivity is less observable) at the beginning of their careers. In that case, gender gaps in sorting should be smaller for older workers, if not in favor of women, in all transitions. Finally, it could be that female workers learn more slowly than men. Then, females would be less likely to be promoted in all firms and to move to better firms.

To check the relevance of these hypotheses, we analyze gender differences in sorting by selecting workers aged 25-30, 30-40, 40-50, or 50-60 in 1995 and following them separately along the sample period.

In the first panel of Table 7, we present results for job transitions by cohort. We find strong 
positive sorting parameters for women, large gender differences for younger cohorts (25-20; 30-40) and weak evidence of sorting for workers 40-50 years old. Sorting is negative or negligible for women and men in the oldest age cohorts. These results, together with the gender-specific wage developments, allow us to rule out the hypothesis that the gender differences in sorting patterns are merely driven by a higher extent of initial mismatches for women with respect to men. However, the case of movers aged 50-60 is very peculiar because a large share of these workers was likely approaching early retirement, which at that time was strongly supported by generous public programs.

The second panel of Table 7 investigates the promotion probability of stayers by cohort. We find that coefficients on the previous wage are similar between men and women for the youngest cohort but a gap emerges for older cohorts: the coefficient for males is twice (one and one-half times) larger than that for females for the cohort 50-60 (40-50). The last panel of Table 7 examines promotions to the managerial level: gender differences are significant in all cohorts, although the probability of better workers being promoted is much higher for men when we consider older cohorts. Hence, contrary to the biological differences hypothesis, gender differences in promotions in favor of men are stronger for middle-aged workers.

The discrepancies between men and women in job transitions are also confirmed in the sub-samples that refer to different age groups (see Table A6 of the Online Appendix).

Overall, the analysis by age groups and cohorts yields limited support for the hypothesis that biological differences explain gender gaps. Indeed, while gender differences are more important when career advancements mostly take place, i.e., for workers aged between 35 and 50 years, in line with our baseline results, such differences are in favor of women in job transitions and in favor of men in promotions. These patterns appear instead to be consistent with the idea that women tend to climb the career ladder at a slower pace than men; hence, women exhibit an increasing gap with respect to men. This lowers a woman's probability of reaching top-level positions.

\subsection{Parenthood}

Several studies suggest that career advancement is more difficult for women due to motherhood (Datta Gupta, Smith, and Verner, 2008; Smith et al., 2013; Kleven et al., 2015; Gallen, 2015). We now test this hypothesis.

While parenthood per se does not appear to be relevant to job transitions (see Tables A17 and A18 of the Online Appendix), the impact of parenthood on career advancement varies substantially across firms.

Indeed, Table 8 reports the results by firm type (female-, not female-friendly, female- and not female-sought companies) for the sub-samples before and after the first child is born. Female-friendly firms show no gender differences in promotions to better occupations before the first child is born, while a small bias in favor of females emerges after the first child is born. However, women who work in other firms encounter a significant penalty in promotion, especially after bearing a child. Regarding promotions to managerial positions, gender differences appear in all firms independent of parenthood. However, the parenthood penalty is harsher in not female-sought and not-female-friendly firms after the first child is born.

Overall, this set of results provides evidence of an interplay between motherhood and the 
glass ceiling phenomenon in certain firms.

\subsection{Further Checks}

Our results could be due to a different distribution of skills, endowments and impediments across genders. Alternatively, women may find good jobs in specific occupations or sectors where their skills are more valued. Yet, gender gaps in job transitions also emerge when we sub-sample by occupation and by education (Table A7 of the Online Appendix): men generally show weaker positive sorting patterns in job transitions, and the difference between genders is larger for blue-collar workers and for workers with primary education, whereas it decreases for more educated workers and for those with better occupations. The latter result is fairly consistent with Card et al. (2016), who conclude that sorting differences across genders are less important for highly educated workers and managers.

Manning (2003), Ch. 7, documents that women in the UK are more constrained in their opportunities to change jobs. We test whether the costs associated with job mobility affect our results by focusing on transitions without a change of residence and for single women, as we expect such costs to be lower in these samples. We find that sorting in job transitions is stronger for women although slightly less so than in baseline regression (Table A8 of the Online Appendix). This suggests that our main results do not entirely depend on the costs associated with changing employers but rather on career concerns. Conversely, the reductions in the labor supply that are represented by shifts from full-time to part-time employment are not associated with positive sorting, as changes in the number of hours worked are likely to be triggered by family considerations. Further, the finding that the sorting coefficient in job transitions is significantly higher for women with a family network might reflect the importance for women of having good connections.

It does not appear to be relevant whether movers find a job in the same industry or in a different industry, which emphasizes that the results are not driven by women self-selecting into particular industries (Table A9 of the Online Appendix). Consistent with this view, our results on job transitions do not depend on firm size (Table A10 of the Online Appendix).

Regarding promotions, estimations conducted separately by education show that gender differences in promotion are lower for workers with mandatory and tertiary education compared to workers with secondary education (Table A11 of the Online Appendix). Results by industry indicate that the same pattern generally emerges in all sectors (Table A12 of the Online Appendix).

While our model predicts that better workers are either more likely to quit jobs in order to move to better firms or to be promoted within the current firm, it is silent on the curvature of these relationships. However, the descriptive analysis in Figure $\mathbf{2}$ and $\mathbf{3}$ seems to suggest a convex relationship between workers' type and either the probability of transition to better firms or the probability of promotion, respectively. We now assess the presence of non-linearities by adding to our main specification the square of workers' wages (Table A13 of the Online Appendix). We find suggestive evidence in support of a convex relationship between workers' type, sorting and promotion for female workers. For men the results with a non linear specification are not always precisely estimated. Hypothesis testing confirms the gender differences highlighted in the main analysis. 
Finally, our main results reported in Table 2 may be driven by the fact that we focus on a selected sample of workers because we rule out part-timers and employees of small firms or firms with imputed accounting variables. The first two panels of Table A16 of the Online Appendix allow us to dismiss these concerns. We obtain a similar impression of the gender differences in sorting and promotion even when we estimate our main models on less-selected samples, either including part-time employees ${ }^{\mathrm{xvi}}$ or employees of small firms.

Another concern is that our analysis is based exclusively on workers in the private sector. Indeed, female workers are more likely to take a more "family-friendly" occupation in the public sector after the first child is born than their male counterparts. While the analysis of sorting cannot be extended to the public sector due to the absence of a measure of firms' performance for public firms, we can extend the analysis of promotion to the public sector. When we do so, there is a considerable gender gap in promotion in favor of men even for this broader sample of workers (third panel of Table A16 of the Online Appendix).

\section{Conclusions}

In this paper, we measure gender differences in sorting by using Danish employer-employee matched data to study gaps in labor market outcomes. Our methodology is centered on the relationship between workers' ability, measured by their position in the wage hierarchy in a given firm, and the probability of moving to a better firm or the probability of being promoted. We find that the degree of positive sorting is higher for women than for men in voluntary job transitions, while it is higher for men than for women in promotions, especially in firms that have fewer female workers in white collar positions than their respective industry mean.

Our detailed account of gender differences provides support for the hypothesis that female workers encounter glass ceilings in some firms. This obstacle is likely to lead good female workers to seek firms that will reward their talents in a fair manner. As a result, good female workers are more mobile than male workers in the direction of better firms, while it is easier for good male workers to be promoted. Nonetheless, gender differences in promotion persist and are similar in all firms when we focus on large career advances.

The gender differences in sorting that we document are broadly consistent with an overall gender gap in labor market outcomes and an under-representation of women in top positions, as observed in the case of Denmark. Since mobility is a way to circumvent gender-biased promotion policies in certain firms, we expect gender gaps to be even more severe in countries with less flexible labor markets.

Furthermore, our findings suggest that women who become mothers have difficulties advancing in their careers in certain firms. These hurdles may be associated with the significant generosity of parental leave policies, as suggested by Datta Gupta et al. (2008). Thus, it is important to conduct further research to determine why these effects emerge and why they do so only in some firms. 
Figure 1: Probability of changing firms against the deviation of estimated residual wages earned in the sending firm.

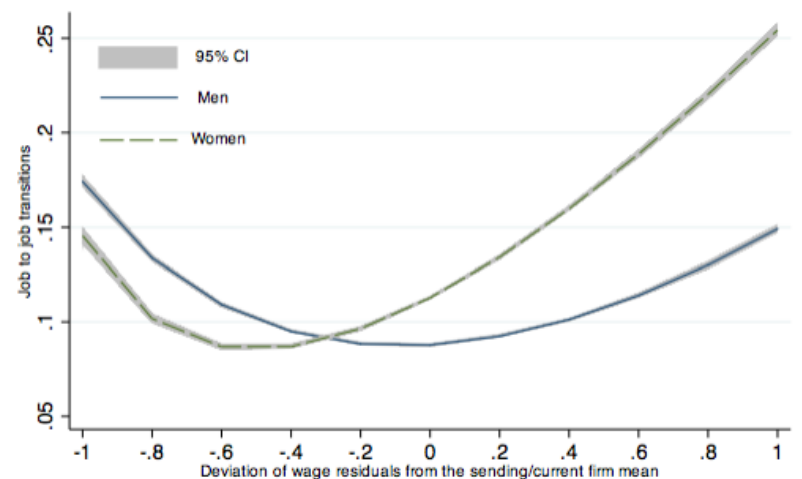

Notes: Residual wages are predicted from a Mincerian regression in which we include the following variables: age and age squared, tenure and tenure squared, marital status, education level, family network, experience and experience squared, occupational dummies, share of white collar women employed in the sending firm, firm fixed effects and dummies for having children, foreigners, sending firm's size and years.

Figure 2: Conditional probability of moving to a better firm against the deviation of estimated residual wages earned in the sending firm.

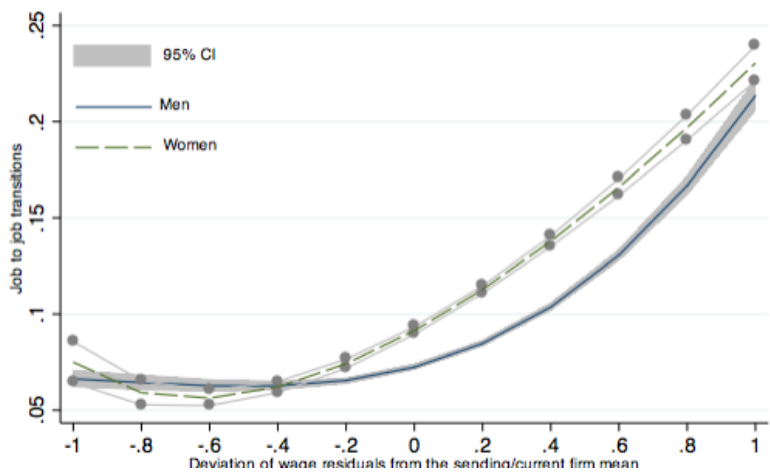

Notes: Residual wages are predicted from a Mincerian regression in which we include the following variables: age and age squared, tenure and tenure squared, marital status, education level, family network, experience and experience squared, occupational dummies, share of white collar women employed in the sending firm, firm fixed effects and dummies for having children, foreigners, sending firm's size and years.

Figure 3: Probability of promotion against the deviation against the deviation of estimated residual wages earned in the current firm.

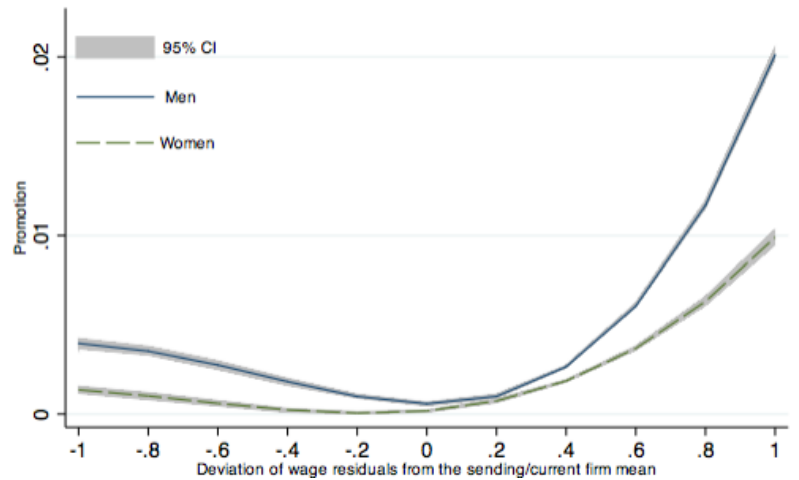

Notes: Residual wages are predicted from a Mincerian regression in which we include the following variables: age and age squared, tenure and tenure squared, marital status, education level, family network, experience and experience squared, occupational dummies, share of white collar women employed in the sending firm, firm fixed effects and dummies for having children, foreigners, sending firm's size and years. 
Table 1: Descriptive statistics

\begin{tabular}{|c|c|c|c|c|c|c|c|c|}
\hline \multirow[t]{3}{*}{ Variables } & \multicolumn{4}{|c|}{ Sample of movers } & \multicolumn{4}{|c|}{ Sample of stayers } \\
\hline & \multicolumn{2}{|c|}{ Women } & \multicolumn{2}{|c|}{ Men } & \multicolumn{2}{|c|}{ Women } & \multicolumn{2}{|c|}{ Men } \\
\hline & Mean & S.d. & Mean & S.d. & Mean & S.d. & Mean & S.d. \\
\hline Log of wage (in sending firm) & 12.206 & 0.506 & 12.430 & 0.522 & 12.293 & 0.429 & 12.542 & 0.426 \\
\hline Age & 37.748 & 9.055 & 38.594 & 9.345 & 39.819 & 9.281 & 40.983 & 9.554 \\
\hline Tenure & 3.561 & 3.795 & 3.487 & 3.809 & 5.567 & 4.877 & 5.931 & 5.126 \\
\hline Labor market experience & 14.118 & 8.358 & 16.602 & 9.152 & 15.638 & 8.278 & 18.884 & 9.161 \\
\hline Manager & 0.024 & 0.155 & 0.041 & 0.199 & 0.018 & 0.131 & 0.046 & 0.208 \\
\hline Middle manager & 0.260 & 0.438 & 0.239 & 0.427 & 0.299 & 0.458 & 0.258 & 0.437 \\
\hline Blue collar & 0.716 & 0.451 & 0.719 & 0.449 & 0.683 & 0.465 & 0.697 & 0.460 \\
\hline With at least a child (0-3) & 0.149 & 0.356 & 0.148 & 0.355 & 0.125 & 0.331 & 0.125 & 0.331 \\
\hline $\begin{array}{l}\text { Primary ( } 1 \text {, if with primary } \\
\text { education) }\end{array}$ & 0.366 & 0.482 & 0.300 & 0.458 & 0.380 & 0.485 & 0.292 & 0.455 \\
\hline $\begin{array}{l}\text { Secondary ( } 1 \text {, if with secondary } \\
\text { and post-secondary education) }\end{array}$ & 0.561 & 0.496 & 0.644 & 0.479 & 0.552 & 0.497 & 0.650 & 0.477 \\
\hline $\begin{array}{l}\text { Tertiary ( } 1 \text {, if with tertiary } \\
\text { education) }\end{array}$ & 0.073 & 0.260 & 0.056 & 0.230 & 0.068 & 0.252 & 0.058 & 0.233 \\
\hline Foreigner & 0.051 & 0.220 & 0.049 & 0.216 & 0.048 & 0.213 & 0.046 & 0.209 \\
\hline $\begin{array}{l}\text { Family network ( } 1 \text {, if one parent is } \\
\text { manager) }\end{array}$ & 0.050 & 0.217 & 0.041 & 0.198 & 0.049 & 0.217 & 0.041 & 0.199 \\
\hline Married or cohabiting & 0.740 & 0.439 & 0.732 & 0.443 & 0.783 & 0.412 & 0.767 & 0.423 \\
\hline $\begin{array}{l}\text { Share of white-collar women in } \\
\text { the sending firm }\end{array}$ & 0.091 & 1.772 & 0.065 & 1.637 & & & & \\
\hline $\begin{array}{l}\text { Share of white-collar women in } \\
\text { the current firm }\end{array}$ & 0.186 & 2.864 & 0.109 & 1.617 & 0.031 & 0.050 & 0.017 & 0.036 \\
\hline $\begin{array}{l}\text { Sending firm size less than } 50 \\
\text { employees }\end{array}$ & 0.118 & 0.323 & 0.166 & 0.372 & & & & \\
\hline $\begin{array}{l}\text { Sending firm size between } 51 \text { and } \\
100 \text { employees }\end{array}$ & 0.102 & 0.303 & 0.131 & 0.338 & & & & \\
\hline $\begin{array}{l}\text { Sending firm size more than } 100 \\
\text { employees }\end{array}$ & 0.780 & 0.415 & 0.703 & 0.457 & & & & \\
\hline $\begin{array}{l}\text { Current firm size less than } 50 \\
\text { employees }\end{array}$ & 0.140 & 0.347 & 0.188 & 0.391 & 0.147 & 0.354 & 0.194 & 0.395 \\
\hline $\begin{array}{l}\text { current firm size between } 51 \text { and } \\
100 \text { employees }\end{array}$ & 0.112 & 0.315 & 0.139 & 0.346 & 0.117 & 0.321 & 0.144 & 0.351 \\
\hline $\begin{array}{l}\text { Current firm size more than } 100 \\
\text { employees }\end{array}$ & 0.748 & 0.434 & 0.673 & 0.469 & 0.736 & 0.441 & 0.662 & 0.473 \\
\hline $\begin{array}{l}\text { Sending firm accounting profit } \\
\text { before taxes per worker }\end{array}$ & 86.292 & 288.338 & 87.682 & 278.075 & & & & \\
\hline $\begin{array}{l}\text { Current firm accounting profit } \\
\text { before taxes per worker }\end{array}$ & 100.746 & 482.845 & 96.862 & 440.232 & 71.103 & 3288.197 & 87.630 & 2311.018 \\
\hline $\begin{array}{l}\text { Prob(profits of current firm } \\
>\text { profits of previous firm by } 5 \% \text { ) }\end{array}$ & 0.401 & 0.493 & 0.378 & 0.490 & & & & \\
\hline $\begin{array}{l}\text { Prob(profits of current firm profits } \\
>\text { of previous firm by } 10 \% \text { ) }\end{array}$ & 0.356 & 0.412 & 0.349 & 0.402 & & & & \\
\hline Promotion (better occupation) & & & & & 0.030 & 0.109 & 0.032 & 0.144 \\
\hline Promotion (manager) & & & & & 0.033 & 0.028 & 0.035 & 0.055 \\
\hline Obs & \multicolumn{2}{|c|}{126,676} & \multicolumn{2}{|c|}{294,073} & \multicolumn{2}{|c|}{$1,329,800$} & \multicolumn{2}{|c|}{$2,773,928$} \\
\hline Number of individuals & \multicolumn{2}{|c|}{97,502} & \multicolumn{2}{|c|}{218,542} & \multicolumn{2}{|c|}{368,810} & \multicolumn{2}{|c|}{663,237} \\
\hline Number of firms & \multicolumn{4}{|c|}{16,764} & \multicolumn{4}{|c|}{18,034} \\
\hline
\end{tabular}

Notes: All the variables are averages from 1996 to 2005. 
Table 2: Sorting in job transitions and promotions: main results

\begin{tabular}{|c|c|c|c|c|c|c|}
\hline & \multicolumn{2}{|c|}{ Sorting in job transitions } & \multicolumn{2}{|c|}{ Promotions } & \multicolumn{2}{|c|}{ Promotions to manager } \\
\hline & Women & Men & Women & Men & Women & Men \\
\hline \multirow[t]{2}{*}{ Log of wage (in sending firm) } & $0.016^{* * *}$ & $0.007 * * *$ & $0.013 * * *$ & $0.023 * * *$ & $0.002 * * *$ & $0.007^{* * *}$ \\
\hline & $(0.000)$ & $(0.001)$ & $(0.002)$ & $(0.003)$ & $(0.000)$ & $(0.001)$ \\
\hline Percentage of white-collar & $-0.078 * * *$ & $0.097 * * *$ & & & & \\
\hline women in sendıng firm & $(0.000)$ & $(0.000)$ & & & & \\
\hline $\begin{array}{l}\text { Percentage of white-collar } \\
\text { women in receiving firm }\end{array}$ & $\begin{array}{c}0.062 * * * \\
(0.000)\end{array}$ & $\begin{array}{c}0.091^{* * *} \\
(0.000)\end{array}$ & & & & \\
\hline Share of white-collar women & & & $0.780 * * *$ & $0.676 * * *$ & $0.017 * * *$ & $0.041 * * *$ \\
\hline in the firm & & & $(0.039)$ & $(0.021)$ & $(0.003)$ & $(0.004)$ \\
\hline $\mathrm{N}$ & 126,676 & 294,073 & $1,329,800$ & $2,773,928$ & $1,329,800$ & $2,773,928$ \\
\hline$R^{2}$ & 0.124 & 0.130 & 0.019 & 0.021 & 0.004 & 0.011 \\
\hline
\end{tabular}

Hypothesis test [ $\chi^{2} ; \mathrm{p}$-value]:

$\alpha_{1}^{\text {women }}=\alpha_{1}^{\text {men }} \quad 149.50 ; 0.000 \quad 110.78 ; 0.000 \quad 323.27 ; 0.000$

Notes: *Statistically significant at the .10 level, **at the .05 level, and ***at the .01 level. For job transitions, the dependent variable is a dummy that takes value 1 if the worker moves to a firm with profits that are at least $5 \%$ higher than those of the previous firm. For promotions, the dependent variable is a dummy that takes value 1 if the worker is, within the same firm, promoted to a higher occupational level. For promotions to managerial positions, the dependent variable is a dummy that takes value one if the worker is, within the same firm, promoted to a managerial occupational level. All specifications include age and age squared, tenure and tenure squared, marital status, having children, education level, family network, a dummy for foreigners, experience and experience squared, firm fixed effects, firm size dummies (both receiving and sending firm in the regressions regarding job transitions), year and occupational dummies. The standard errors reported in parentheses are clustered at the sending firm level and at the individual level.

Table 3: Sorting in job transitions and promotions by female friendliness of firms

\begin{tabular}{|c|c|c|c|c|}
\hline & \multicolumn{4}{|c|}{ Sorting in job transitions } \\
\hline & \multicolumn{2}{|c|}{ Transition to female-friendly firms } & \multicolumn{2}{|c|}{ Transition not to female-friendly firms } \\
\hline & Women & Men & Women & Men \\
\hline Log of wage in sending firm & $\begin{array}{c}0.023 * * * \\
(0.003)\end{array}$ & $\begin{array}{c}0.005^{* * *} \\
(0.000)\end{array}$ & $\begin{array}{c}0.006 * * * \\
(0.002)\end{array}$ & $\begin{array}{c}0.007 * * * \\
(0.002)\end{array}$ \\
\hline $\bar{N}$ & 77,383 & 157,585 & 49,293 & 136,488 \\
\hline$R^{2}$ & 0.098 & 0.109 & 0.165 & 0.150 \\
\hline
\end{tabular}

Hypothesis test [ $\chi^{2} ; \mathrm{p}$-value]:

\begin{tabular}{|c|c|c|c|c|c|c|}
\hline \multirow[t]{2}{*}{$\alpha_{1}^{\text {women }}=\alpha_{1}^{\text {men }}$} & \multicolumn{3}{|c|}{$27.51 ; 0.000$} & \multicolumn{3}{|c|}{$0.02 ; 0.897$} \\
\hline & \multicolumn{6}{|c|}{ Promotions } \\
\hline & \multicolumn{2}{|c|}{ Female-friendly firms } & \multicolumn{2}{|c|}{ Non-female-friendly firms } & \multicolumn{2}{|c|}{ Female-sought firms } \\
\hline & Women & Men & Women & Men & Women & Men \\
\hline Log of wage & $\begin{array}{c}0.015^{* * *} * \\
(0.003)\end{array}$ & $\begin{array}{c}0.012^{* * *} \\
(0.003)\end{array}$ & $\begin{array}{c}0.011^{* *} \\
(0.001)\end{array}$ & $\begin{array}{c}0.025^{* * *} \\
(0.003)\end{array}$ & $\begin{array}{c}0.014 * * * \\
(0.003)\end{array}$ & $\begin{array}{c}0.009 * * * \\
(0.002)\end{array}$ \\
\hline $\mathrm{N}$ & 459,405 & 574,378 & 870,395 & $2,199,550$ & 391,628 & 449,077 \\
\hline$R^{2}$ & 0.019 & 0.023 & 0.009 & 0.022 & 0.027 & 0.033 \\
\hline
\end{tabular}

Hypothesis test [ $\chi^{2} ; \mathrm{p}$-value]:

\begin{tabular}{|c|c|c|c|c|c|c|}
\hline \multirow[t]{4}{*}{$\alpha_{1}^{\text {women }}=\alpha_{1}^{\text {men }}$} & \multicolumn{2}{|c|}{$31.57 ; 0.000$} & \multicolumn{2}{|c|}{$134.60 ; 0.000$} & \multicolumn{2}{|c|}{$62.82 ; 0.000$} \\
\hline & \multicolumn{6}{|c|}{ Promotions to managerial occupation } \\
\hline & \multicolumn{2}{|c|}{ Female-friendly firms } & \multicolumn{2}{|c|}{ Not female-friendly firms } & \multicolumn{2}{|c|}{ Female-sought firms } \\
\hline & Women & Men & Women & Men & Women & Men \\
\hline Log of wage & $\begin{array}{c}0.003^{* * *} \\
(0.000)\end{array}$ & $\begin{array}{c}0.007^{* * *} * \\
(0.000)\end{array}$ & $\begin{array}{c}0.002^{* * *} \\
(0.000)\end{array}$ & $\begin{array}{c}0.007^{* * *} \\
(0.000)\end{array}$ & $\begin{array}{c}0.003^{* * *} \\
(0.000)\end{array}$ & $\begin{array}{c}0.006 * * * \\
(0.000)\end{array}$ \\
\hline $\mathrm{N}$ & 459,405 & 574,378 & 870,395 & $2,199,550$ & 391,628 & 449,077 \\
\hline$R^{2}$ & 0.005 & 0.009 & 0.003 & 0.012 & 0.005 & 0.009 \\
\hline
\end{tabular}

Hypothesis test [ $\chi^{2} ; \mathrm{p}$-value]:

$\alpha_{1}^{\text {women }}=\alpha_{1}^{\text {men }} \quad 69.26 ; 0.000$

$376.79 ; 0.000$

$93.37 ; 0.000$

Notes: *Statistically significant at the .10 level, **at the .05 level, and ***at the .01 level. For promotions, the dependent variable is a dummy that takes value 1 if the worker is promoted to a better occupation in the same firm or if the worker is promoted to a managerial occupational level in the same firm. All specifications include the same controls as the regressions in Table 2. The standard errors reported in parentheses are clustered at the sending firm level and at the individual level. 
Table 4: Sorting in job transitions and promotions using fixed effects from AKM

\begin{tabular}{|c|c|c|c|c|c|c|}
\hline & \multicolumn{2}{|c|}{ Sorting in job transitions } & \multicolumn{2}{|c|}{ Promotions } & \multicolumn{2}{|c|}{ Promotions to manager } \\
\hline & Women & Men & Women & Men & Women & Men \\
\hline Individual fixed effects & $\begin{array}{c}0.032^{* * *} \\
(0.002)\end{array}$ & $\begin{array}{c}0.011^{* * *} \\
(0.001)\end{array}$ & $\begin{array}{c}0.038^{* * *} \\
(0.003)\end{array}$ & $\begin{array}{c}0.065^{* * *} \\
(0.001)\end{array}$ & $\begin{array}{c}0.005^{* * *} \\
(0.000)\end{array}$ & $\begin{array}{c}0.020 * * * \\
(0.001)\end{array}$ \\
\hline$\overline{\mathrm{N}}$ & 123,154 & 287,100 & $1,310,132$ & $2,735,987$ & $1,310,132$ & $2,735,987$ \\
\hline$R^{2}$ & 0.126 & 0.130 & 0.023 & 0.032 & 0.005 & 0.017 \\
\hline
\end{tabular}

\begin{tabular}{ll} 
Hypothesis test [ $\chi^{2} ;$ & $1201.36 ; 0.000$ \\
p-value $] \alpha_{1}^{\text {women }}=\alpha_{1}^{\text {men }}$ & $146.55 ; 0.000$ \\
\hline
\end{tabular}

Notes: *Statistically significant at the .10 level, **at the .05 level, and ***at the .01 level. All specifications include the same dependent variables and controls as the regressions in Table 2. The standard errors reported in parentheses are clustered at the sending firm and at the individual level.

Table 5: Sorting in job transitions using the methodology from BDM

\begin{tabular}{|c|c|c|c|c|c|c|}
\hline & \multicolumn{2}{|c|}{ Strength of sorting } & \multicolumn{2}{|c|}{ Sign of sorting (1) } & \multicolumn{2}{|c|}{ Sign of sorting (2) } \\
\hline & Women & Men & Women & Men & Women & Men \\
\hline $\begin{array}{l}\text { Sending firm's profits per } \\
\text { worker }\end{array}$ & $\begin{array}{c}0.345^{* * *} \\
(0.003)\end{array}$ & $\begin{array}{c}0.253^{* * *} \\
(0.002)\end{array}$ & & & & \\
\hline$\eta$ as in BDM & 0.587 & 0.503 & & & & \\
\hline $\begin{array}{l}\text { Log of wage in } \\
\text { receiving firm }\end{array}$ & & & $\begin{array}{c}0.173^{* * *} \\
(0.011)\end{array}$ & $\begin{array}{c}0.094^{* * *} \\
(0.007)\end{array}$ & & \\
\hline $\begin{array}{l}\text { Log of wage in } \\
\text { sending firm }\end{array}$ & & & & & $\begin{array}{c}0.039 * * * \\
(0.006)\end{array}$ & $\begin{array}{c}0.010 * * * \\
(0.003)\end{array}$ \\
\hline $\mathrm{N}$ & 78,842 & 199,233 & 78,842 & 199,233 & 78,842 & 199,233 \\
\hline$R^{2}$ & 0.464 & 0.359 & 0.146 & 0.063 & 0.693 & 0.625 \\
\hline
\end{tabular}

Hypothesis test [ $\chi^{2}$;

p-value] $\alpha_{1}^{\text {women }}=\alpha_{1}^{\text {men }}$

$777.86 ; 0.000$

Notes: *Statistically significant at the .10 level, **at the .05 level, and ***at the .01 level. In the first and last two columns, the dependent variable is the receiving firm's profits per worker. In the third and fourth columns, the dependent variable is the sending firm's profits per worker.

Table 6: Sorting in job transitions by type of transitions

\begin{tabular}{|c|c|c|c|c|}
\hline & \multicolumn{2}{|c|}{ Profits > 10\% } & \multicolumn{2}{|c|}{ Wage improvement } \\
\hline & Women & Men & Women & Men \\
\hline Log of wage in sending firm & $\begin{array}{c}0.014 * * * \\
(0.000)\end{array}$ & $\begin{array}{c}0.005^{* * *} \\
(0.001)\end{array}$ & $\begin{array}{c}0.020 * * * \\
(0.003)\end{array}$ & $\begin{array}{r}0.009 * * * \\
(0.002)\end{array}$ \\
\hline $\mathrm{N}$ & 126,676 & 294,073 & 50,943 & 97,662 \\
\hline$R^{2}$ & 0.122 & 0.130 & 0.204 & 0.169 \\
\hline
\end{tabular}

Hypothesis test [ $\chi^{2} ; \mathrm{p}$-value]:

$\alpha_{1}^{\text {women }}=\alpha_{1}^{\text {men }}$

$67.72 ; 0.000$

47.08; 0.000

\begin{tabular}{|c|c|c|c|c|}
\hline & \multicolumn{2}{|c|}{ Better occupational level } & \multicolumn{2}{|c|}{ Transitions from firm exit } \\
\hline & Women & Men & Women & Men \\
\hline \multirow[t]{2}{*}{ Log of wage in sending firm } & $0.017 * * *$ & $0.003 * * *$ & $0.009 * * *$ & $0.011 * * *$ \\
\hline & $(0.001)$ & $(0.001)$ & $(0.000)$ & $(0.000)$ \\
\hline $\mathrm{N}$ & 17,520 & 39,878 & 26,083 & 57,820 \\
\hline$R^{2}$ & 0.112 & 0.118 & 0.084 & 0.117 \\
\hline
\end{tabular}

Hypothesis test [ $\chi^{2} ; \mathrm{p}$-value]:

$\alpha_{1}^{\text {women }}=\alpha_{1}^{\text {men }}$

250.99; 0.000

$11.05 ; 0.000$

Notes: *Statistically significant at the .10 level, **at the .05 level, and ***at the .01 level. All specifications include the same controls as the regressions in Table 2 . The standard errors reported in parentheses are clustered at the sending firm level and at the individual level. 
Table 7: Sorting in job transitions and promotions: results by cohort

\begin{tabular}{|c|c|c|c|c|}
\hline & \multicolumn{4}{|c|}{ Sorting in job transitions } \\
\hline & Cohort 25-30 & Cohort 30-40 & Cohort 40-50 & Cohort 50-60 \\
\hline & \multicolumn{4}{|c|}{ Women } \\
\hline \multirow[t]{2}{*}{ Log of wage in sending firm } & $0.026 * * *$ & $0.029 * * *$ & $0.005^{* * *}$ & $-0.020 * * *$ \\
\hline & $(0.001)$ & $(0.004)$ & $(0.001)$ & $(0.000)$ \\
\hline $\bar{N}$ & 2,876 & 3,679 & 1,945 & 630 \\
\hline \multirow[t]{2}{*}{$R^{2}$} & 0.143 & 0.142 & 0.134 & 0.211 \\
\hline & \multicolumn{4}{|c|}{ Men } \\
\hline Log of wage in sending firm & $\begin{array}{c}0.002^{* * *} \\
(0.001) \\
\end{array}$ & $\begin{array}{c}0.009^{* * *} \\
(0.002)\end{array}$ & $\begin{array}{c}-0.001 \\
(0.001))\end{array}$ & $\begin{array}{c}-0.001^{* * *} \\
(0.000)\end{array}$ \\
\hline$\overline{\mathrm{N}}$ & 11,124 & 16,982 & 9,133 & 4,027 \\
\hline$R^{2}$ & 0.153 & 0.142 & 0.129 & 0.123 \\
\hline \multicolumn{5}{|c|}{ Hypothesis test [ $\chi^{2} ; \mathrm{p}$-value]: } \\
\hline \multirow[t]{4}{*}{$\alpha_{1}^{\text {women }}=\alpha_{1}^{\text {men }}$} & $1046.97 ; 0.000$ & $92.37 ; 0.000$ & $8.49 ; 0.000$ & $683.65 ; 0.000$ \\
\hline & \multicolumn{4}{|c|}{ Promotions } \\
\hline & Cohort 25-30 & Cohort $30-40$ & Cohort $40-50$ & Cohort 50-60 \\
\hline & \multicolumn{4}{|c|}{ Women } \\
\hline Log of wage & $\begin{array}{c}0.018^{* * *} \\
(0.001)\end{array}$ & $\begin{array}{c}0.029^{* * *} \\
(0.002)\end{array}$ & $\begin{array}{c}0.039^{* * *} \\
(0.002)\end{array}$ & $\begin{array}{c}0.044^{* * *} \\
(0.002)\end{array}$ \\
\hline $\bar{N}$ & 121,018 & 199,285 & 175,239 & 52,682 \\
\hline \multirow[t]{2}{*}{$R^{2}$} & 0.025 & 0.030 & 0.033 & 0.032 \\
\hline & \multicolumn{4}{|c|}{ Men } \\
\hline \multirow[t]{2}{*}{ Log of wage } & $0.018^{* * *}$ & $0.041^{* * *}$ & $0.059 * * *$ & $0.091^{* * *}$ \\
\hline & $(0.002)$ & $(0.001)$ & $(0.002)$ & $(0.003)$ \\
\hline$\overline{\mathrm{N}}$ & 271,866 & 477,224 & 451,131 & 169,002 \\
\hline$R^{2}$ & 0.024 & 0.037 & 0.047 & 0.062 \\
\hline \multicolumn{5}{|c|}{ Hypothesis test $\left[\chi^{2} ; p\right.$-value]: } \\
\hline \multirow[t]{4}{*}{$\alpha_{1}^{\text {women }}=\alpha_{1}^{\text {men }}$} & $0.01 ; 0.90$ & $25.50 ; 0.000$ & $34.18 ; 0.000$ & $102.02 ; 0.000$ \\
\hline & \multicolumn{4}{|c|}{ Promotions to managerial occupations } \\
\hline & Cohort 20-30 & Cohort $30-40$ & Cohort 40-50 & Cohort 50-60 \\
\hline & \multicolumn{4}{|c|}{ Women } \\
\hline \multirow[t]{2}{*}{ Log of wage } & $0.002^{* * *}$ & $0.005^{* * *}$ & $0.007^{* * *}$ & $0.007^{* * *}$ \\
\hline & $(0.000)$ & $(0.000)$ & $(0.000)$ & $(0.001)$ \\
\hline $\bar{N}$ & 121,018 & 199,285 & 175,239 & 52,682 \\
\hline \multirow[t]{2}{*}{$\underline{R}^{2}$} & 0.004 & 0.015 & 0.011 & 0.007 \\
\hline & \multicolumn{4}{|c|}{ Men } \\
\hline \multirow[t]{2}{*}{ Log of wage } & $0.003^{* * *}$ & $0.013^{* * *}$ & $0.019 * * *$ & $0.038^{* * *}$ \\
\hline & $(0.000)$ & $(0.000)$ & $(0.000)$ & $(0.003)$ \\
\hline $\bar{N}$ & 271,866 & 477,224 & 451,131 & 169,002 \\
\hline$\underline{R^{2}}$ & 0.005 & 0.025 & 0.024 & 0.035 \\
\hline \multicolumn{5}{|c|}{ Hypothesis test [ $\chi^{2} ; p$-value]: } \\
\hline$\alpha_{1}^{\text {women }}=\alpha_{1}^{\text {men }}$ & $15.09 ; 0.000$ & $169.49 ; 0.000$ & $123.23 ; 0.000$ & $72.21 ; 0.000$ \\
\hline
\end{tabular}

Notes: *Statistically significant at the .10 level, **at the .05 level, and ***at the .01 level. All specifications include the same dependent variables and controls as the regressions in Table 2 . The standard errors reported in parentheses are clustered at the sending firm level and at the individual level. 
Table 8: Sorting in promotions by female friendliness of firms before and after children

\begin{tabular}{|c|c|c|c|c|}
\hline & \multicolumn{4}{|c|}{ Promotion to better occupation } \\
\hline & \multicolumn{2}{|c|}{ Before Child } & \multicolumn{2}{|c|}{ After Child } \\
\hline & Female-friendly firms & Not female-friendly firms & Female-friendly firms & Not female-friendly firms \\
\hline & \multicolumn{4}{|c|}{ Women } \\
\hline \multirow[t]{2}{*}{ Log of wage } & 0.001 & $0.007 * * *$ & $0.016^{* * *}$ & $0.008 * * *$ \\
\hline & $(0.002)$ & $(0.002)$ & $(0.003)$ & $(0.000)$ \\
\hline $\bar{N}$ & 26,911 & 45,141 & 50,562 & 85,368 \\
\hline$R^{2}$ & 0.036 & 0.010 & 0.024 & 0.010 \\
\hline & \multicolumn{4}{|c|}{ Men } \\
\hline \multirow[t]{2}{*}{ Log of wage } & -0.002 & $0.016 * * *$ & $0.014^{* * *}$ & $0.019 * * *$ \\
\hline & $(0.003)$ & $(0.001)$ & $(0.004)$ & $(0.003)$ \\
\hline $\mathrm{N}$ & 35,508 & 117,046 & 64,697 & 210,860 \\
\hline$R^{2}$ & 0.043 & 0.020 & 0.010 & 0.011 \\
\hline \multicolumn{5}{|c|}{ Hypothesis test [ $\chi^{2} ; \mathrm{p}$-value]: } \\
\hline \multirow[t]{4}{*}{$\alpha_{1}^{\text {women }}=\alpha_{1}^{\text {men }}$} & $1.36 ; 0.243$ & $23.75 ; 0.000$ & $3.61 ; 0.091$ & $27.12 ; 0.000$ \\
\hline & \multicolumn{2}{|c|}{ Before Child } & \multicolumn{2}{|c|}{ After Child } \\
\hline & Female-sought firms & Not female-sought firms & Female-sought Firms & Not female-sought firms \\
\hline & \multicolumn{4}{|c|}{ Women } \\
\hline \multirow[t]{2}{*}{ Log of wage } & 0.004 & $0.008 * * *$ & $0.027^{* * *}$ & 0.009 \\
\hline & $(0.004)$ & $(0.003)$ & $(0.006)$ & $(0.001)$ \\
\hline $\mathrm{N}$ & 6,134 & 13,525 & 10,123 & 22,970 \\
\hline$R^{2}$ & 0.026 & 0.020 & 0.009 & 0.007 \\
\hline & \multicolumn{4}{|c|}{ Men } \\
\hline \multirow[t]{2}{*}{ Log of wage } & $0.013^{* * *}$ & $0.015^{* * *}$ & $0.021^{* * *}$ & $0.018^{* * *}$ \\
\hline & $(0.003)$ & $(0.005)$ & $(0.007)$ & $(0.003)$ \\
\hline $\bar{N}$ & 15,652 & 57,017 & 26,358 & 94,273 \\
\hline$R^{2}$ & 0.033 & 0.014 & 0.023 & 0.012 \\
\hline \multicolumn{5}{|c|}{ Hypothesis test [ $\chi^{2} ; \mathrm{p}$-value]: } \\
\hline \multirow[t]{5}{*}{$\alpha_{1}^{\text {women }}=\alpha_{1}^{\text {men }}$} & $5.92 ; 0.014$ & $7.18 ; 0.007$ & $6.59 ; 0.012$ & $14.80 ; 0.000$ \\
\hline & \multicolumn{4}{|c|}{ Promotion to managerial occupation } \\
\hline & $\mathrm{Be}$ & Child & & Child \\
\hline & Female-friendly firms & Not female-friendly firms & Female-friendly firms & Not female-friendly firms \\
\hline & & & & \\
\hline Log of wage & $0.003^{* * *}$ & $0.001 * * *$ & $0.002 * * *$ & $0.001 * * *$ \\
\hline & $(0.000)$ & $(0.000)$ & $(0.000)$ & $(0.000)$ \\
\hline$\overline{\mathrm{N}}$ & 26,911 & 45,141 & 50,562 & 85,368 \\
\hline$R^{2}$ & 0.004 & 0.001 & 0.003 & 0.002 \\
\hline & & & & \\
\hline Log of wage & $0.004^{* * *}$ & $0.004 * * *$ & $0.005^{* * *}$ & $0.004 * * *$ \\
\hline & $(0.000)$ & $(0.000)$ & $(0.001)$ & $(0.000)$ \\
\hline $\mathrm{N}$ & 35,508 & 117,046 & 64,697 & 210,860 \\
\hline$R^{2}$ & 0.007 & 0.009 & 0.004 & 0.004 \\
\hline Hypothesis test [ & & & & \\
\hline$\alpha_{1}^{\text {women }}=\alpha_{1}^{\text {men }}$ & $2.74 ; 0.098$ & $18.72 ; 0.000$ & $4.77 ; 0.029$ & $26.30 ; 0.000$ \\
\hline & $\mathrm{Be}$ & Child & & Child \\
\hline & Female-sought Firms & Not female-sought firms & Female-sought Firms & Not female-sought firms \\
\hline & & & & \\
\hline Log of wage & $0.004 * *$ & $0.001^{* * *}$ & $0.004^{* *}$ & $0.001^{* *}$ \\
\hline & $(0.002)$ & $(0.000)$ & $(0.001)$ & $(0.000)$ \\
\hline$\overline{\mathrm{N}}$ & 6,134 & 13,525 & 10,123 & 22,970 \\
\hline$R^{2}$ & 0.009 & 0.003 & 0.008 & 0.003 \\
\hline & & & & \\
\hline Log of wage & $0.008 * * *$ & $0.004^{* * *}$ & $0.003^{* *}$ & $0.003 * * *$ \\
\hline & $(0.001)$ & $(0.000)$ & $(0.001)$ & $(0.000)$ \\
\hline $\mathrm{N}$ & 15,652 & 57,017 & 26,358 & 94,273 \\
\hline$R^{2}$ & 0.011 & 0.008 & 0.004 & 0.005 \\
\hline Hypothesis test [ & & & & \\
\hline$\alpha_{1}^{\text {women }}=\alpha_{1}^{\text {men }}$ & $3.29 ; 0.069$ & $51.43 ; 0.000$ & $0.25 ; 0.61$ & $8.90 ; 0.002$ \\
\hline
\end{tabular}


Notes: *Statistically significant at the .10 level, **at the .05 level, and ***at the .01 level. The dependent variable is a dummy that takes value 1 if the worker is promoted to a better (or to a managerial) occupation in the same firm. All specifications include the same controls as the regressions in Table 2. Female-friendly firms are those with a share of white-collar women higher than the industrial mean. Female-sought firms only include the destination firms of the job transitions model with a share of white-collar women that is higher than the industrial mean that hired at least one woman in the sorting model. Standard errors reported in parentheses are clustered at the sending firm level and at the individual level.

\section{Appendix: Theoretical Framework}

There is a unit mass of workers, half of which are males and the rest females, and a unit mass of firms offering one job. ${ }^{\text {xvii }}$ A share $\delta \in(0,1)$ of firms are female friendly-the definition of which will be explained shortly. There are three periods-0, 1 and 2,-and there is no discounting across periods. Workers and firms are heterogeneous in terms of their productivity. Workers at time 0 draw their type $e_{0}$ independent of their gender from a distribution $\Gamma_{0}(e)$ with smooth density $\gamma_{0}(e)$ on $(0,1 / \tau], \tau>1$. Firms draw their type $f$ from distribution $\Upsilon(f)$ independent of their female friendliness, with a smooth density $v(f)$ on $[0,1]$.

When types $e$ and $f$ form a match, they produce output $Y(e, f)$. Unmatched agents obtain a payoff of zero. We assume the following production function in each period:

$$
Y(e, f)=\alpha e^{\theta} f^{\theta}+h(e)+g(f)
$$

where $h(\cdot)$ and $g(\cdot)$ are increasing functions such that $h(0)=g(0)=0$, while $\alpha>0$ and $\theta>0$ are parameters that indicate the strength of the complementarities. We denote an assignment of workers to firms as $\mu$. Since $Y_{e f}>0$, this production function induces positive assortative matching in a frictionless economy, i.e., $\mu(e)=f$ (Becker, 1973). ${ }^{\text {viii }}$

Wages are determined by bargaining, with workers' bargaining power being equal to $1 / 2$. Unemployment benefits are normalized to zero.

At time 0 , workers and firms are randomly matched after their respective types have been realized. At this point, they cannot search for another match. Production takes place, and wages are paid. Since output is non-negative and agents cannot search, all agents will prefer to match, and there is no outside option. Hence, wages are determined by bargaining with inside options and with disagreement payoffs equal to zero. Hence, the worker and the firm both obtain half of the output. ${ }^{\text {xix }}$

A worker $e_{0}$ in a match in period 0 with a firm $f$ such that $e_{0} \geq f$ becomes of type $\tau e_{0}$ in period 1 . This can be interpreted as learning by doing: during period 0 , workers acquire relevant experience that improves their skills as long as $e_{0} \geq f$. As a result, in the second period, workers are more productive, i.e., they increase their type. We denote by $\Gamma_{1}(e)$ the new distribution of types, which, given the random allocation in period 0 , is a smooth distribution on $(0,1]$. In other words, there are skill requirements (Merlino, 2016): only agents that are sufficiently qualified understand the technology enough to improve their productivity.

However, not-female-friendly firms do not allow female workers who learned to express their acquired potential. Formally, the output of such a match in the first period remains $Y(e, f)$, while if the female worker moves to a female-friendly firm $f^{\prime}$, she produces 
$Y\left(\tau e, f^{\prime}\right)$. We label by $P$ those matches in which promotions could take place, i.e., all matches except those in which a female worker is employed in a not-female-friendly firm.

In period 1, each pair can decide whether to stay together or to search for a better partner. Those pairs that decide not to stay together do not produce but search at a constant cost of $c$. They are then matched in period 2 according to the frictionless allocation. Wages in period 1 are determined by Nash bargaining.

In period 2 , given $e$, which is equal to $e_{0}$ or $\tau e_{0}$ depending on whether the worker learned or not, wages in the frictionless allocation are given by

$$
\max _{e} Y(e, f)-w_{2}(e) \text {. }
$$

Since $Y_{e}>0$ and $Y_{f}>0$, workers and firms can be ranked according to their productivity. Then, it is without loss of generality to index a worker by her rank in terms of productivity, i.e., by the fraction of workers who are less productive than her. Similarly, we can identify each firm by its rank in the distribution of firm productivity. This means that the distributions $\Gamma_{1}(\cdot)$ and $\Upsilon(\cdot)$ in the second period are both uniform on $(0,1)$.

The timing of the model is summarized in Figure 4.

Figure 4: The timing of the model

\begin{tabular}{lllll} 
& $1 .(\mathrm{i})$ & \multicolumn{1}{c}{ 1.(ii) } & \multicolumn{1}{c}{ 2.(i) } & 2.(ii) \\
$\begin{array}{l}0 \\
\text { random matching } \\
\text { \& production }\end{array}$ & $\begin{array}{l}\text { learning \& } \\
\text { promotion }\end{array}$ & separation or & frictionless search & production \\
production & at cost $c>0$ &
\end{tabular}

The maximization problem in $(\mathrm{A}-2)$ yields ${ }^{\mathrm{xx}}$

$$
\begin{aligned}
& w^{a ̊}(e)=\int_{0}^{e} \frac{\partial Y(\tilde{e}, \mu(\widetilde{e}))}{\partial e} d \Gamma_{1}(\widetilde{e})=\frac{\alpha}{2} e^{2 \theta}+h(e), \\
& \pi^{\AA}(f)=\int_{0}^{f} \frac{\partial Y\left(\mu^{-1}(\tilde{f}), \widetilde{f}\right)}{\partial \widetilde{f}} d \Upsilon(\widetilde{f})=\frac{\alpha}{2} f^{2 \theta}+g(f) .
\end{aligned}
$$

A worker $e$ who stays matched with a firm $f$ receives in period 1 a wage equal to half of the surplus generated by the match, denoted by $S(e, f)$, plus his outside option, that is, the match in the instantaneous frictionless allocation net of the search cost. Hence,

$$
w_{1}(e, f)=\frac{1}{2} S(e, f)+w^{a ̊ a}(e)-c
$$

A pair will remain matched in period 1 if both the worker and the firm involved in the match prefer to stay together rather than face a holdout period, pay $c$ and be matched with their optimal type in the frictionless allocation in period 2. In other words, the worker or the firm will not sever the match if the surplus generated $S(e, f)$ is positive.

This implies that match $(e, f) \in P$ will not be destroyed if $e \in A_{1}^{P}(f)$, where ${ }^{\mathrm{xxi}}$

$$
A_{1}^{P}(f)=\left[\left(f^{\theta}-2 \sqrt{\frac{c}{\alpha}}\right)^{1 / \theta}, \overline{\bar{e}}\right]
$$

and $\overline{\bar{e}}=\left(f^{\theta}+2 \sqrt{c / \alpha}\right)^{1 / \theta} / \tau$. Hence, it is more likely that a firm and worker will not leave their 
match if they are not too mismatched. A match $(e, f) \notin P$ denotes instead female workers employed in not-female-friendly firms. Such matches will not be destroyed if

$$
e \in A_{1}^{\neg P}=\left[\left(f^{\theta}-2 \sqrt{\frac{c}{\alpha}}\right)^{1 / \theta}, \bar{e}\right],
$$

and $\bar{e}=\left\lfloor\alpha f^{b}+\sqrt{4 \alpha c \tau+\alpha f^{2 \theta}\left(1-\tau^{2}\right)}\right\rfloor(\alpha \tau)$. Clearly, $\bar{e}<\overline{\bar{e}}$ : since female workers employed in not-female-friendly firms are not promoted, they are more likely to search due to more attractive outside options. Then, these observations immediately follow.

Remark 1 Wages and (total or average) profits in period 1 are increasing in own type. Wages are non-monotonic in firm type.

Proof of Remark 1 The surplus of a match $(e, f)$ is

$$
S(e, f)=\left\{\begin{array}{lc}
\alpha(\tau e)^{\theta} f^{\theta}-\frac{\alpha}{2}(\tau e)^{2 \theta}-\frac{\alpha}{2} f^{2 \theta}+2 c & \text { ife } \geq f \operatorname{and}(e, f) \in P, \\
\alpha e^{\theta} f^{\theta}-\frac{\alpha}{2}(\tau e)^{2 \theta}-\frac{\alpha}{2} f^{2 \theta}+2 c & \text { if } e \geq f \operatorname{fand}(e, f) \notin P, \\
\alpha e^{\theta} f^{\theta}-\frac{\alpha}{2}(e)^{2 \theta}-\frac{\alpha}{2} f^{2 \theta}+2 c & \text { otherwise. }
\end{array}\right.
$$

Substituting $(A-3)$ and $(A-7)$ into $(A-4)$, the following wage rate in period 1 results:

$$
w_{1}(e, f)=\left\{\begin{array}{lc}
\frac{\alpha}{2}(\tau e)^{\theta} f^{\theta}+\frac{\alpha}{4}(\tau e)^{2 \theta}-\frac{\alpha}{4} f^{2 \theta}+h(e)+2 c & \text { ife } \geq f \text { and }(e, f) \in P, \\
\frac{\alpha}{2} e^{\theta} f^{\theta}+\frac{\alpha}{4}(\tau e)^{2 \theta}-\frac{\alpha}{4} f^{2 \theta}+h(e)+2 c & \text { if } e \geq f \text { fand }(e, f) \notin P, \\
\frac{\alpha}{2}(e)^{\theta} f^{\theta}+\frac{\alpha}{4}(e)^{2 \theta}-\frac{\alpha}{4} f^{2 \theta}+h(e)+2 c & \text { otherwise, }
\end{array}\right.
$$

which is increasing in $e$ and non-monotone in $f$. Then, since profits are what is left from production after paying the wage, we have

$$
\pi_{1}(e, f)=\left\{\begin{array}{lc}
\frac{\alpha}{2}(\tau e)^{\theta} f^{\theta}-\frac{\alpha}{4}(\tau e)^{2 \theta}+\frac{\alpha}{4} f^{2 \theta}+g(f)+2 c & \text { ife } \geq f \operatorname{and}(e, f) \in P, \\
\frac{\alpha}{2} e^{\theta} f^{\theta}-\frac{\alpha}{4}(\tau e)^{2 \theta}+\frac{\alpha}{4} f^{2 \theta}+g(f)+2 c & \text { if } \geq \text { fand }(e, f) \notin P, \\
\frac{\alpha}{2}(e)^{\theta} f^{\theta}-\frac{\alpha}{4}(e)^{2 \theta}+\frac{\alpha}{4} f^{2 \theta}+g(f)+2 c & \text { otherwise, }
\end{array}\right.
$$

which is increasing in $f$. Since the boundaries of the acceptance set are increasing in the 
firm's type, mean payoffs conditional on being matched are also increasing in agents' own types in the case of multi-worker firms. This concludes the proof of Remark 1.

Remark 1 implies that we can rank workers using their position in the wage distribution in a given firm. However, since wages are non-monotonic in firm type, it is not possible from wage data alone to detect sorting (Eeckhout and Kircher, 2011).

On average, we can rank firms using profits. Since different firms might have different pools of workers, it could be that a good firm matched with bad agents has worse profits than a bad firm matched with a good agent. Nonetheless, the possibility of search imposes bounds on the degree of mismatch that can arise, allowing for a correct ranking of firms. Hence, by examining job transitions, it is possible to identify the sign and strength of sorting.

Given the acceptance sets of the different types of firms, we can now state the empirical predictions of the theoretical framework with regard to gender differences in sorting.

Proposition 1 Assume that production is given by $(A-1), \delta \in(\bar{\delta}, 1)$ and $\tau \in(1, \bar{\tau})$. Consider $e_{m}$ and $e_{f}$ such that $e_{m}$ is male, $e_{f}$ is female and $e_{m}=e_{f}=e$. Then,

(i) the higher $e$ in a given firm is, the higher the probability of moving to a better firm;

(ii) the probability of moving to a better firm from a given firm for $e_{f}$ with respect to $e_{f}-\Delta$ is higher than for $e_{m}$ with respect to $e_{m}-\Delta$, for $\Delta>0$; and

(iii) the probability of being promoted in a given firm for $e_{m}$ with respect to $e_{m}-\Delta$ is higher than for $e_{f}$ with respect to $e_{f}-\Delta$, for $\Delta>0$.

Proof of Proposition 1. The measure of workers who move from female-friendly firms is

$$
\int_{0}^{1} \int_{e \notin A_{1}^{P}(f)} \delta \Gamma(e) d \Upsilon(f)
$$

while the measure of female workers who move from not-female-friendly firms is

$$
\int_{0}^{1} \int_{e \notin A_{1} P}(f) \frac{1}{2}(1-\delta) d \Gamma(e) d \Upsilon(f) .
$$

Since (A-8) is increasing in $\delta$ while (A-9) is decreasing in $\delta$, there exists a $\bar{\delta}$ such that for all $\delta>\bar{\delta}$, all female workers moving from not-female-friendly firms can match with a female-friendly firm in the frictionless market.

Furthermore, it is easy to see from (A-5) that $\overline{\bar{e}}$ is always larger than $f$, i.e., there will be some promotions, if $\tau<\bar{\tau}$, where $\bar{\tau}=(2 \sqrt{c / \alpha})^{1 / \theta}$.

Inspecting (A-5) and (A-6), a worker moves to a better firm if $e>\bar{e}$ or $e>\overline{\bar{e}}$, depending on the firm type. Thus, result (i) follows. Furthermore, $\bar{e}<\overline{\bar{e}}$, such that (ii) and (iii) also follow. This concludes the proof.

In other words, female workers who improve their type through learning but are not promoted are more likely to move to better firms, while good male workers are more likely to be promoted in the firm where they are currently employed. 


\section{References}

John M. Abowd, Francis Kramarz, and David N. Margolis. 1999. High wage workers and high wage firms. Econometrica, 67(2): 251-333.

Joshua D. Angrist and Alan B. Krueger. 2001. Instrumental variables and the search for identification: From supply and demand to natural experiments. Journal of Economic Perspectives, 15(4): 69-85.

Jesper Bagger and Rasmus Lentz. 2014. An equilibrium model of wage dispersion with sorting. Mimeo.

—, Kenneth L. Sørensen, and Rune Vejlin. 2013. Wage sorting trends. Economics Letters, 118(1): $63-67$.

Cristian Bartolucci, Francesco Devicienti, and Ignacio Monzón. 2015. Identifying sorting in practice. Mimeo.

— and - 2013. Better workers move to better firms: A simple test to identify sorting. Mimeo.

Kimberly Bayard, Judith Hellerstein, David Neumark, and Kenneth Troske. 2003. New evidence on sex segregation and sex differences in wages from matched employee-employer data. Journal of Labor Economics, 21(4): 887-922.

Gary S Becker. 1973. A theory of marriage: Part I. Journal of Political Economy, 81(4): 813-46.

Alison L. Booth, Marco Francesconi, and Jeff Frank. 2003. A sticky floors model of promotion, pay, and gender. European Economic Review, 47(2): 295-322.

David Card, Ana Rute Cardoso, and Patrick Kline. 2016. Bargaining, sorting, and the gender wage gap: Quantifying the impact of firms on the relative pay of women. The Quarterly Journal of Economics, 131(2): 633-686.

—, Jörg Heining, and Patrick Kline. 2013. Workplace heterogeneity and the rise of west german wage inequality. The Quarterly Journal of Economics, 128(3): 967-1015.

Nabanita Datta Gupta, Nina Smith, and Mette Verner. 2008. The impact of nordic countries' family friendly policies on employment, wages, and children. Review of Economics of the Household, 6(1): 65-89.

Jan Eeckhout and Philipp Kircher. 2011. Identifying sorting-in theory. Review of Economic Studies, 78(3): 872-906.

Tor Eriksson and Niels Westergaard-Nielsen. 2009. Wage and labor mobility in Denmark, 1980-2000. In The Structure of Wages: An International Comparison, pp. 101-123. University of Chicago Press.

Antonio Filippin and Jan C. Ours. 2015. Positive assortative matching: Evidence from sports data. Industrial Relations: A Journal of Economy and Society, 54(3): 401-421. 
Yana Gallen. 2015. The gender productivity gap. Mimeo.

George-Levi Gayle, Limor Golan, and Robert A. Miller. 2012. Gender differences in executive compensation and job mobility. Journal of Labor Economics, 30: 829-872.

Fane Groes, Philipp Kircher, and lourii Manovskii. 2015. The u-shapes of occupational mobility. The Review of Economic Studies, 82(2): 659-692.

Marcus Hagedorn, Tzuo Hann Law, and lourii Manovskii. 2017. Identifying equilibrium models of labor market sorting. Econometrica, 85(1): 29-65.

Judith K. Hellerstein and David Neumark. 2008. Workplace segregation in the united states: Race, ethnicity, and skill. Review of Economics and Statistics, 90(3): 459-477.

Boris Hirsch. 2016. Gender wage discrimination. IZA World of Labor, 310.

Andrea Ichino and Enrico Moretti. 2009. Biological gender differences, absenteeism, and the earnings gap. American Economic Journal: Applied Economics, 1: 183-218.

Henrik Kleven, Camille Landais, and Jakob Søgaard. 2015. Children and gender inequality: Evidence from denmark. Mimeo.

Edward P. Lazear and Sherwin Rosen. 1999. Male-female wage differentials in job ladders. Journal of Labor Economics, 8(1): S106-S123

Alan Manning. 2003. Monopsony in Motion: Imperfect Competition in Labor Markets. Princeton: Princeton University Press.

Luca P. Merlino. 2012. Discrimination, technology and unemployment. Labour Economics, 19(4): 557-567.

-. 2016. Efficient sorting in frictional labor markets with two-sided heterogeneity. Macroeconomic Dynamics, 20(1): 95-119.

OECD. 2005. Labour force statistics 1984-2004. Paris.

Pierpaolo Parrotta and Dario Pozzoli. 2012. The effect of learning by hiring on productivity. The RAND Journal of Economics, 43(1): 167-185.

Kathryn Shaw and Edward P. Lazear. 2008. Tenure and output. Labour Economics, 15(4): 704723.

Nina Smith, Valdemar Smith, and Mette Verner. 2013. Why are so few females promoted into ceo and vice president positions? danish empirical evidence, 1997-2007. Industrial and Labor Relations Review, 66(2): 380-408.

Douglas A Webber. 2016. Firm-level monopsony and the gender pay gap. Industrial Relations: $A$ Journal of Economy and Society, 55(2): 323-345.

World Economic Forum. 2015. Global Gender Gap Report. 


\section{Notes}

i According to the 2015 Global Gender Gap Report (World Economic Forum, 2015), Denmark ranks 14th and 81st (out of 145 countries) on the gender wage gap and on the gender gap among legislators, senior officials, and managers.

ii Less-profitable discriminatory firms may survive competition with non-discriminatory firms for several reasons. First, social enforcement may result in less lost profit in discriminatory firms. Second, there may be clients with discriminatory tastes. Third, search frictions may facilitate social enforcement.

iii The Danish registers provide the actual work experience measured as total years of employment. Tenure of workers hired since 1980 can be calculated directly from the registers. Tenure for job spells started before 1980 is left censored. In our preferred specification we include age, work experience and job tenure separately. However our main results are robust to the exclusion of either age or work experience from the main specification (Table A1 of the Online Appendix).

iv In the main specification we control for firm size dummies. However we obtain very similar results if we use the log of employees as a control of firm size (Table A1 of the Online Appendix).

"We estimate equation 1 with OLS after we have centered both the dependent and independent variable using a within-firm transformation to control for firm fixed effects. While such an approach is not obviously inferior to a logit model if the "right" non-linear model is unknown (Angrist and Krueger, 2001), its results are easy to interpret, and it allows an easy implementation of hypothesis testing on the difference between coefficients estimated across sub-samples. Specifically, we estimate

$$
\text { move_up } p_{e t}\left(f, f^{\prime}\right)=\widetilde{\alpha}_{0}+\alpha_{1} \tilde{w} a g e_{e t-1}(f)+\widetilde{x}_{e t-1}{ }^{\prime} \beta+\widetilde{z}_{f t-1}{ }^{\prime} \gamma_{1}+\widetilde{z}_{f^{\prime} t}{ }^{\prime} \gamma_{2}+\widetilde{z}_{t}+\widetilde{\varepsilon}_{e t},
$$

where the tilde reflects the within-firm transformed data in which the firm mean has been removed from each individual observation and which removes the term $u_{f}$.

vi As for (1), we estimate equation (2) with OLS on the transformed data.

vii We exclude firms with fewer than 20 employees, as they do not have a sufficient number of transitions to compare male and female movers as required by our empirical strategy. Furthermore, because we rank firms based on their profits, we exclude public firms for which profits are not a stated objective.

viii We exclude from the sample the extreme observations of the annual salary, i.e., those lower than the 1st percentile and higher than the 99th percentile of the salary distribution. Annual salary is adjusted for possible unemployment spells during the year. We address the issue of measurement error related to the use of annual data on wages in a robustness check, where we use the wages of the November spell, which are available for only some workers in our sample. For those employees who work for fewer than 365 days at the firm corresponding to the November spell (approximately 35 percent), we annualize their wages using information on the duration of the same spell. The results obtained from this spell-specific measure of wages are similar to those of the main analysis (Table A2 in the Online Appendix). 
ix We allow periods of unemployment between the previous and the current job. In one of our robustness checks, we focus on job transitions without periods of unemployment between jobs (Table A15 of the online Appendix).

${ }^{x}$ The descriptive statistics of the original population of movers and stayers before applying any of our sample selection criteria are reported in Table A3 of the Online Appendix. The demographic and labor market characteristics are not too dissimilar across the different samples, although in our chosen samples, both female and male workers earn higher wages on average are more likely to have at least one child and to have a secondary education. In terms of firm size, our samples over-represent firms with more than 50 employees. This is because firms' accounting variables are available for the entire population of firms with more than 50 employees and only for a representative sample of firms with fewer than 50 employees. For completeness, we also report in Table A3 the descriptive statistics of the entire Danish workforce, including the public sector, and of the workforce employed in the public sector alone over the sample period. Interestingly, the average characteristics of female workers in the public sector are fairly comparable to those reported for our samples of female movers and stayers. The share of female white collar workers is however larger in the public sector compared to this share in both of our samples. This is consistent with the notion that public employment is a more family-friendly environment and less prone to gender discrimination in promotions. In one of our robustness checks, we assess whether the exclusion of the public sector affects our main results on promotion. We could not replicate our main results on sorting for the public sector, as firms' accounting variables are not available for the public sector.

xi Transitions to better firms are more likely for workers who are married, parents or native citizens and for those who hold tertiary education. Age, tenure and having a parent with past managerial experience are not significantly correlated with sorting. These coefficients are not reported.

xii Native and marital status, higher education and family networks are positively associated with the likelihood of being promoted conditional on staying at the same firm. These coefficients are not reported.

xiii In this case, a one-standard-deviation increase in the log of lagged wages increases the promotion probability at the managerial level by 2.6 percent and 8.5 percent for male and female workers, respectively.

xiv This methodology is based on the identification of connected sets of firms. Those consist of firms that have movers in common. Due to the high mobility that characterizes the Danish labor market and the relatively long time period considered, the largest connected set contains more than $99 \%$ of the workers and firms in the sample. Moreover, this methodology relies on the assumption of "conditional exogenous mobility". Following Card et al. (2013), we assess its plausibility by considering all possible cases in which this assumption may be violated. Figure A4 of the Online Appendix supports the idea that the worker-firm matching is based on a combination of permanent firm and individual characteristics that do not create major concerns for the estimation of the wage equation above.

$x v$ Another solution would be to estimate the average wage for a worker estimated in a sample over all job spells (Hagedorn, Law, and Manovskii, 2017). However, average wages per worker 
cannot be precisely estimated since workers are normally matched with one firm per spell and they firms few times.

xvi When we include part-timers in the sample, we use the log of hourly wages as a measure of workers' ranking. Hourly wages are reliable for a smaller sample, and hence, the sample size is lower compared to the main analysis even if we include both full- and part-time workers.

xvii It is possible to assume a measure $M \in(0,1) \cap Q$ of firms each posting $1 / M$ jobs, and the same results would be obtained since there would still be a job for each worker.

xviii While we assume a particular production function, we refer the reader to Eeckhout and Kircher (2011) for a more general formulation, albeit in a model without promotions. If $Y^{-}(e, f)=\alpha e^{\theta}(1-f)^{\theta}+h(e)+g(f)$, then $Y_{e f}<0$ : this would induce negative sorting.

${ }^{x i x}$ Assuming no asymmetric information, wages could be derived using Nash bargaining-this solution concept is not axiomatically justified when there is asymmetric information. Since agents cannot search except in period 2, wages would then be given by $Y_{0}(e, f) / 2+S(e, f) / 2+w^{*}(e)+c$ if there is no learning, where $S(e, f)$ is the surplus of the match in period 1 and the wage in the frictionless allocation. A similar expression would arise if there is learning. Even in that case, wages in period 0 would be increasing in own type in a given firm conditional on gender. This is all our identification strategy requires.

${ }^{x x}$ Since in period 2 firms' gender biases are realized, in the frictionless allocation, female workers will be matched with female-friendly firms. The symmetry in the model ensures that there are always enough female-friendly firms that female workers who decide to search can always find such a firm.

${ }^{x \times i}$ For the sake of brevity, we abstract here from boundary conditions resulting from the fact that for low types surplus might not exceed the total search cost of $2 c$. To avoid keeping track of endogenous entry, we assume that agents will search even if that is the case. 